\title{
PARA A HISTÓRIA DA CONVOCAÇÃO DAS CORTES CONSTITUINTES EM PORTUGAL EM 1820: A PROPOSTA "CORPORATIVISTA" DE ANTÓNIO DE ALMEIDA
}

\section{TOWARDS THE HISTORY OF THE CONVOCATION OF THE CONSTITUENT CORTES IN PORTUGAL IN 1820: THE ANTÓNIO DE ALMEIDA'S “CORPORATIST" PROPOSAL}

\author{
José Domingues \\ Universidade Lusíada - Norte (Porto) \\ Vital Moreira \\ Universidade Lusiada - Norte (Porto) / Universidade de Coimbra
}

SUMÁRIO: INTRODUÇÃO. I. DADOS BIOGRÁFICOS SOBRE O AUTOR DO PARECER. II. CONTEÚDO DO PARECER. 2.1. Restrições aos direitos políticos. 2.2. Representação de indole corporativista. 2.3. As categorias representadas. 2.3.1. Representação dos proprietários. 2.3.2. Representação das "cidades e vilas consideráveis". 2.3.3. Representação dos negociantes e fabricantes. 2.3.4. Representação do clero secular. 2.3.5. Representação do clero regular. 2.3.6. Representação da Universidade. 2.3.7. Representação da Academia das Ciências. 2.3.8. Representação da magistratura. 2.3.9. Representação do exército. 2.3.10. Representação da Companhia dos Vinhos do Alto Douro. 2.4. Composição das Cortes e estatuto dos deputados. III. IMCOMPATIBILIDADE COM OS PRINCÍPIOS DA REPRESENTAÇÃO LIBERAL. CONCLUSÃO.

Resumo: A partir do dia 1 de outubro de 1820, a unificação da Junta Provisória de Governo do Porto, instituída com a revolução de 24 de agosto, com o Governo Interino de Lisboa, nomeado no dia 15 de setembro, ficou consolidada a ideia de uma "regeneração política" do País, assente na convocação das Cortes para a elaboração de uma Constituição. No entanto, como as Cortes portuguesas não reuniam há mais de um século, levantou-se a questão de saber qual seria o melhor sistema de representação nacional, adequada às luzes do século XIX. Para tentar obter resposta, numa primeira manifestação do princípio da soberania nacional, a Junta Preparatória das Cortes promoveu uma extensa "consulta externa", por portaria de 6 de outubro de 1820, particularmente dirigida à sociedade letrada. Foram emitidas mais de duas mil circulares a solicitar a opinião de indivíduos letrados e esclarecidos, bem como das instituições científicas da Universidade de Coimbra e da Academia das Ciências de Lisboa, sobre a convocação das futuras Cortes Constituintes. Este artigo traz à colação o parecer inédito do médico António de Almeida, que propôs uma original representação política nacional de índole corporativista. Independentemente da repercução que possa ter tido naquela época, hoje é mais um fragmento ímpar do processo constituinte de 1820 , que ilustra uma notável página desconhecida da história da representação política em Portugal. 
Abstract: From October 1, 1820, onwards, the unification of the Provisional Government of Oporto, established with the revolution of August 24, with the Interim Government of Lisbon, set up on September 15, the idea of a "political regeneration" of the Country based on the convening of the Cortes for the adoption of a Constitution was definitly consolidated. However, since the traditional Portuguese Cortes had not been covened for more than a century, the question arose as to what would be the best national representation system, suited to the conditions of the nineteenth century. In order to reach an answer, the Junta Preparatoria of the Cortes promoted an extensive external consultation procedure on October 6, 1820. More than two thousand invitations were issued requesting the opinion of knowlegeable and enlightened individuals, as well as of the two mais scientific institutions, the University of Coimbra and the Academy of Sciences of Lisbon, on the best way to convene the future Constituent Cortes. This article brings to light the unpublished opinion of doctor António de Almeida, who proposed an original political representation scheme of a corporatist nature. Regardless of the repercussion it may have had at that time, today it is another unique fragment of the constituent procedure of 1820 , wich illustrates a remarkable, yet unknown, page of the history of political representation in Portugal.

Palavras chave: Liberalismo, Cortes de 1820, Representação Política, Soberania Popular.

Key words: Liberalism, Cortes of 1820, Political Representation, Popular Sovereignty.

\section{INTRODUÇÃO}

Este ano de 2020 comemora-se o bicentenário do constitucionalismo moderno em Portugal, com lastro na Revolução Liberal iniciada na cidade do Porto, a 24 de agosto de 1820. "A regeneração de 24 de agosto de 1820 até ao fim de maio de 1823 -asseverava Freire de Carvalho, poucos anos depois- foi outra nova luz que apareceu na longa noite tenebrosa da nossa servidão e das nossas misérias"1. Desde o primeiro instante, os lideres vintistas anunciaram uma "regeneração politica" do País assente na convocação das Cortes e na consequente adoção de uma Constituição escrita, que se viria a concretizar com a primeira Constituição Política da Monarquia Portuguesa, aprovada pelas Cortes a 23 de setembro de 1822, jurada pelos deputados constituintes no dia 30 de setembro, pelo rei no dia 1 de outubro e pelo reino no dia 3 de novembro desse ano.

Mas as Cortes não eram convocadas há 123 anos, pois a última convocatória tinha sido feita para a cidade de Lisboa por D. Pedro II, em 1697; não obstante, persistia bem acesa uma tradição juspolítica multissecular que avalizava a sua convocação, sobretudo, em momentos de grave crise política, institucional, económica e social. Prima facie, estavam reunidas todas as condições necessárias

\footnotetext{
${ }^{1}$ José Liberato Freire de CARVAlHo, Ensaio Histórico-Político sobre a Constituição e o Governo do Reino de Portugal, Paris, em Casa de Hector Bossange, 1830, p. 312.
} 
para que, em 1820, a estratégia de convocar as Cortes agradasse a todos e fosse acolhida sem grandes reservas.

No entanto, apesar de todos concordarem e aclamarem a convocação das Cortes, não tardou a surgir a primeira dificuldade aos proponentes revolucionários do Porto: segundo a Constituição tradicional da monarquia portuguesa, a competência para convocar as Cortes pertencia ao rei, que desde $1807 / 08$ se tinha exilado no Brasil, em fuga à primeira invasão napoleónica ao território português. De imediato, os governadores do Reino em Lisboa, que governavam em nome de D. João VI, tentaram apoderar-se da iniciativa da Junta Provisional governativa portuense invocando a dita prerrogativa régia e assumindo-se "como os legitimos representantes de el-rei e, na sua ausência, os únicos com legitimidade para convocar as Cortes, jogando a legitimidade tradicional do rei contra a legitimidade revolucionária do governo provisório"2.

Sem perda de tempo, a Regência lisboeta, por portaria de 1 de setembro de 1820, nomeou uma Comissão Preparatória ${ }^{3}$ e, no dia 9 desse mês e ano, anunciava a convocação das Cortes para Lisboa, nos moldes tradicionais (ou seja, com representação separada dos três "estados"), com início marcado para o dia 15 de novembro desse ano. No entanto, dois meses antes dessa data, no dia 15 de setembro, um pronunciamento militar em Lisboa, secundando a revolução do Porto, dissolveu a Regência, substituindo-a por um Governo Interino de nomeação popular, alinhado com os ideais da Revolução, o qual passou a coexistir com a Junta do Governo Supremo instituída no Porto no dia 24 de agosto. A portaria de 27 de setembro de 1820, assinada em Alcobaça, acabou com esta bicefalia governativa no campo revolucionário e deu origem a duas novas juntas de âmbito nacional: a Junta Provisional do Governo Supremo do Reino, encarregada do governo e da administração pública; e a Junta Provisional Preparatória das Cortes, esta última subdividida em duas secções (uma para tratar da convocação das Cortes e outra para tratar do seu funcionamento interno) $)^{4}$.

Mas a dualidade do poder político revolucionário de 1820 só terminou definitivamente no dia 1 de outubro, com a entrada triunfante da Junta do Governo Provisório do Porto na capital, dirigindo-se diretamente ao Palácio da Regência, situado na Praça do Rossio, para celebrar o encontro amistoso com os membros homólogos do Governo Interino de Lisboa e se proceder à tomada de posse do novo Governo provisório, agora de âmbito nacional. "Perante este cenário politico, esfumou-se a questão sobre se a Junta Provisional podia ou não convocar as Cortes à margem da vontade do rei. A legitimidade revolucionária triunfou sobre a legitimidade tradicional do monarca"s.

\footnotetext{
2 José Domingues e Vital MoreIRA, "Nas Origens do Constitucionalismo em Portugal: o parecer de J. J. Ferreira Gordo sobre a convocação das Cortes Constituintes em 1820”, in e-Legal History Review 28, 2018, p. 9.

${ }^{3}$ Foram nomeados membros desta Comissão Preparatória das Cortes: D. Frei Patrício da Silva (arcebispo de Évora), Luís António Furtado de Castro do Rio de Mendonça e Faro (conde de Barbacena) -que foi substituído por Joaquim José Ferreira Gordo-, Matias José Dias Azedo (tenente-general conselheiro de guerra), António José Guião (desembargador), Tomás da Silva Monteiro (desembargador) e, para secretário, Manuel Borges Carneiro.

${ }^{4}$ Suplemento à Gazeta de Lisboa, n. ${ }^{\circ}$ 234, Lisboa, quinta-feira: 28 de setembro de 1820.

5 José Domingues e Vital MoreIRA, "Nas Origens do Constitucionalismo em Portugal”, op. cit., pp. 7-16 (13).
} 
Arrumada a questão da legitimidade ou competência para convocar as Cortes, de imediato se levantou uma nova questão -não menos espinhosa do que a anterior- à recém-nomeada Junta Preparatória das Cortes: qual deveria ser a natureza politica das futuras Cortes ou qual seria a melhor forma para alcançar uma boa e eficaz representação política nacional, numa palavra, a mais adequada para fazer a nova Constituição? A resposta que se desse a esta questão primária determinaria a génese formativa e a, daí resultante, autoridade constitucional das futuras Cortes, não só das Cortes extraordinárias constituintes como também das posteriores Cortes ordinárias.

A controvérsia -com matizes que deram origem a posições intermédias como, v. g., a da Academia Real das Ciências, que adotou "uma fórmula conciliatória da legalidade tradicional com as aspirações dos inovadores"- girou entre umas Cortes históricas ou tradicionais, compostas pelos três estados do Reino (clero, nobreza e povo) e presididas pelo rei, que a literatura absolutista do século XVIII tinha remetido à mera função consultiva do poder régio; ou umas Cortes constitucionais modernas, compostas por deputados eleitos pelos cidadãos (à margem de quaisquer privilégios), titulares do voto individual ou per capita, com uma presidência eleita entre si pelos próprios deputados, depositários da soberania da Nação, que lhe legava o poder constituinte -isento de qualquer ingerência do poder régio- para elaborar a nova Constituição ${ }^{7}$ e o poder deliberativo de fazer as leis, com a sanção do rei ${ }^{8}$. Nesta segunda hipótese, as Cortes assumem-se como um autêntico parlamento no sentido moderno, constituído e a funcionar de acordo com as luzes do século vigente e seguindo o exemplo de outros Estados constitucionais, em particular, o da vizinha Espanha.

Perante tal demanda, a recém-nomeada Junta Provisional Preparatória das Cortes -com apoio da ressalva que tinha ficado estabelecida no final da referida portaria de Alcobaça de 27 de setembro: "a Junta, de acordo com todos os seus membros, se reserva o poder de associar aos trabalhos destas duas comissões aquelas pessoas que, por suas luzes e amor da Pátria, se julgarem aptas para cooperar no desempenho dos grandes objetos dos seus trabalhos"-, tomou uma decisão inusitada e, seguramente, bastante avançada para a época, quando, por portaria de 6 de outubro de 1820, determinou que se fizesse uma espécie de "consulta externa" sobre esta matéria. Para executar tal decisão, notificou as duas principais instituições científicas do País -a Universidade de Coimbra e a Academia Real das Ciências de Lisboa- e enviou cerca de duas mil e duzentas circulares impressas "a várias pessoas de reputada literatura e aos titulares, dignidades, ministros e empregados em postos eminentes".

\footnotetext{
${ }^{6}$ Joaquim de CARVAlHo, “A Corrente Regeneradora (Século XIX)”, in Obra Completa VI: História das Instituições e do Pensamento Político, Lisboa, Fundação Calouste Gulbenkian, 1989, p. 66 (este trabalho foi publicado pela primeira vez in História de Portugal, Edição Monumental, vol. VII, Barcelos, Portucalense Editora, 1935, pp. 60-124).

"Somente à Nação pertence fazer a sua Constituição ou Lei Fundamental, por meio de seus representantes legitimamente eleitos" (Bases da Constituição de 1821, art. ${ }^{\circ} 21^{\circ}$ ); à Nação "somente pertence fazer pelos seus deputados, juntos em Cortes, a sua Constituição ou Lei Fundamental, sem dependência de sanção do rei”" (Constituição de 1822 , art. $\left.^{\circ} 27^{\circ}\right)$.

8 “Ao rei pertence dar a sanção à lei”, mas com um veto meramente suspensivo, uma vez que "vencendo-se que, sem embargo delas [razões apresentadas pelo rei para suspender a sanção], passe a lei como estava, será novamente apresentada ao rei que lhe dará logo a sanção" (Constituição de 1822, art. $^{\circ} 110^{\circ}$ ).

${ }^{9}$ José Domingues e Vital MoreIRA, "Nas Origens do Constitucionalismo em Portugal”, op. cit., pp. 16-25 (18).
} 
Nada se sabe sobre o eventual parecer da Universidade de Coimbra -se é que chegou a ser formulado algum parecer institucional!- e desapareceu a grande parte dos pareceres (mais de quinhentos) enviados à Junta Preparatória pelas pessoas e instituições que foram diretamente contactadas para participar nesta tomada de decisão. Mediante tal escassez de dados, é impossivel apurar a amplitude de resposta obtida à "consulta" de 1820. É, no entanto, seguro que ainda nesse ano de 1820 foram publicados vários desses pareceres -o que garantiu a sua preservação e chegada até aos dias de hoje-, nomeadamente os da autoria de José Agostinho de Macedo ${ }^{10}$, José Teotónio Canuto de Forjó ${ }^{11}$ e Francisco José de Almeida ${ }^{12}$. Manuel Borges Carneiro também deixou impressos os traços gerais da sua opinião sobre este assunto, sobretudo criticando o que lhe parecia estar desadequado à nova representação política nacional, através de um aditamento que fez ao seu Portugal Regenerado ${ }^{13}$. O parecer de Fr. Amaro de Nossa Senhora das Verdades, ao que tudo indica, terá sido impresso pela primeira vez em 1822 e, depois, no ano de 1826 -só conseguimos aceder a esta segunda edição-, a seguir à outorga da Carta Constitucional ${ }^{14}$. Uma sintese da decisão tomada pela comissão ad hoc nomeada pela Academia Real das Ciências de Lisboa-composta por cinco dos seus sócios- ficou registada nas memórias de um dos sócios que integrou essa comissão redatorial, Francisco Manuel Trigoso de Aragão Morato ${ }^{15}$.

Seguiu-se um hiato temporal de mais de um século, até que, em 1940, Adriano do Nascimento deu à estampa o parecer inédito de António José das Neves Melo, lente de Retórica e Agricultura da Universidade de Coimbra ${ }^{16}$. Em vida, este autor ainda coligiu mais seis pareceres inéditos -de António Correia de

${ }^{10}$ Parecer de José Agostinho de Macedo, sobre a maneira mais facil, simples e exequivel da convocação das Cortes geraes do Reino no actual Systema Politico da Monarchia representativa e Constitucional, Lisboa, na Typografia Lacerdina, 1820.

${ }^{11}$ Memoria em que deo o seu parecer ao convite das Juntas do Governo Supremo do Reino em 24 de Octubro José Theotonio Canuto de Forjó, Lisboa, na Impressão de Alcobia, 1820.

${ }^{12}$ Introdução à Convocação das Cortes Debaixo das Condições do Juramento Prestado pela Nação. Por Francisco José de Almeida, medico da Camera de sua Magestade, membro da Junta da Saude Publica, censor regio do Desembargo do Paço e socio da Academia Real das Sciencias. Offerecida ao Governo no dia 25 de Outubro de 1820 , Lisboa, na Impressão Régia, 1820.

${ }^{13}$ Manuel Borges CARNEIRO, “Adicionamento: Reflexão sobre as presentes Cortes Extraordinarias”, in Portugal Regenerado em 1820, Lisboa, Typografia Lacerdina, 1820, 2. a edição consideravelmente acrescentada, pp. $72-105$ (3. ${ }^{a}$ edição, pp. 74-107); Zília Osório de CASTRO (introdução e organização), Manuel Borges Carneiro, Portugal Regenerado em 1820, Parábolas Acrescentadas ao Portugal Regenerado, Vila Nova de Famalicão, Edições Húmus, 2017, pp. 65-80. Localizámos o parecer manuscrito original deste autor, que nos permite um cotejo e apurar o que foi excluído e o que foi acrescentado na obra impressa. Cf. Lisboa, BNP - Cod. 10454//19.

${ }^{14}$ Breve Resposta que deo hum religioso capuchino da provincia da conceição deste reino, aos dois problemas politicos que à sua ponderação offereceo a Junta Preparatoria de Cortes, por aviso assignado pelo barão de Molellos, a 12 de outubro de 1820, Lisboa, em a Nova Impressão da Viuva Neves e Filhos, 1826.

${ }^{15}$ Francisco Manuel Trigoso de Aragão Morato, Memórias de Francisco Manuel Trigoso de Aragão Morato: começadas a escrever por ele mesmo em principios de Janeiro de 1824 e terminadas em 15 de julho de 1835, revistas e coordenadas por Ernesto de Campos de Andrada, Coimbra, Imprensa da Universidade, 1933, pp. 102-104; Apontamentos para o Elogio Historico do Illustrissimo e Excellentissimo Senhor Francisco Manoel Trigoso d'Aragão Morato, do Conselho d'Estado, Ministro e Secretario d'Estado Honorario, Par do Reino, Vice-Presidente da Academia Real das Sciencias de Lisboa, etc., colligidos pelo Conde de Lavradio, Lisboa, Typographia da Sociedade Propagadora dos Conhecimentos Uteis, 1840, pp. 8-9; José de Arriaga, História da Revolução Portuguesa de 1820, Volume 2 , Porto, Livraria Portuense Lopes e C. ${ }^{\text {a }}$ - editores, 1887, p. 193.

${ }^{16}$ Adriano do NASCIMENTO - "Coisas de Outros Tempo: Os Ingénuos de 1820", in Diário de Coimbra, de 13 de fevereiro de 1940. 
Joaquim Castro, de António de Araújo Costa Maia, de António de Araújo Travassos, de António José Ferreira Galhardo, de António Hipólito Costa, tenente-general governador das armas de Peniche, e do "digníssimo deputado secretário da Junta Provisional Preparatória das Cortes”, encarregado dos Negócios do Reino, José Joaquim Ferreira de Moura ${ }^{17}$, que juntou ao do referido lente de Coimbra para formar e publicar em coletânea temática, com um texto introdutório e de apresentação sobre a Revolução Liberal de $1820^{18}$.

Muito recentemente apareceu no Arquivo Histórico Parlamentar (Lisboa) o parecer manuscrito autógrafo e, à data, inédito de Joaquim José Ferreira Gordo, que foi publicado na integra, com um estudo analitico e de enquadramento histórico-constitucional sobre a premente necessidade de convocar as Cortes em 1820, que conduziria ao procedimento de "consulta" adotado pela Junta Preparatória das Cortes e ao aparecimento destes múltiplos pareceres sobre a eventual representação nacional e formação das próximas Cortes Constituintes de $1821 / 22^{19}$.

Inventariado o considerável espólio documental que chegou até aos dias de hoje, não podemos deixar de salientar o esquecimento a que tem sido votada pelos historiadores e jushistoriadores uma questão tão relevante para a história constitucional de Portugal -e em particular para a história do parlamentarismo neste País-, que acendeu a controvérsia no seio da Junta Provisional Preparatória das Cortes, abalou a Junta Provisional do Governo Supremo do Reino, chamou à colação a Universidade de Coimbra e a Academia Real das Ciências, abriu as portas à participação externa, sobretudo da comunidade letrada, na tomada da decisão política..., numa só palavra, percorreu o País de lés a lés, contagiando toda a sociedade. Convém sublinhar que foi o "sismo politico de 6 de outubro" que esteve na origem das Instruções eleitorais de 31 de outubro de 1820 (revogadas) e das sucessoras de 22 de novembro de 1820.

Pelo que conseguimos apurar, a esterilidade bibliográfica só não é total porque dois autores, na primeira metade do século XX, lhe fizeram breves referências: o primeiro foi Paulo Merêa, que no trabalho sobre o Poder Real e as Cortes (1923) lhe reservou uma nota sucinta: "uma questão importante que logo se levantou foi a de saber como se devia organizar a representação nacional em cortes. A Junta Provisional, hesitante sobre esse ponto, chegou mesmo a consultar as corporações científicas e os homens conhecidos pela sua profissão literária, prometendo acolher cordialmente quaisquer trabalhos"20; o segundo foi Joaquim de Carvalho, que ao estudar a Corrente Regeneradora do Século XIX (1935), observou que "o pleito pairava desde o dia da Revolução, e desceu ao primeiro plano das preocupações quando a Junta Preparatória das Cortes, pela portaria de 6 de outubro, solicitou alvitres e opiniões"21. Passado o deserto de quase um século,

\footnotetext{
${ }^{17}$ Este parecer está truncado, não permitindo identificar cabalmente o seu autor. Mas uma vez que este se identifica como deputado da Junta Provisional Preparatória das Cortes, encarregado dos Negócios do Reino, pela portaria de 27 de setembro desse ano o nome que foi designado para esse cargo foi o de José Joaquim Ferreira de Moura - cf. Suplemento à Gazeta de Lisboa, n. ${ }^{\circ}$ 234, Lisboa, quinta-feira: 28 de setembro de 1820-.

${ }^{18}$ Adriano do NASCIMENTO - A Revolução de 1820 (documentos inéditos), Coimbra, 1962.

${ }^{19}$ José Domingues e Vital MoreirA, "Nas Origens do Constitucionalismo em Portugal”, op. cit., pp. 1-39.

${ }^{20}$ Paulo MERÊA, "O Poder Real e as Cortes", in Estudos de Filosofia Jurídica e de História das Doutrinas Políticas, Lisboa, Imprensa Nacional-Casa da Moeda, 2004, p. 276 (este trabalho foi publicado pela primeira vez em 1923).

${ }^{21}$ Joaquim de CARVALHO, “A Corrente Regeneradora (Século XIX)”, op. cit., p. 66.
} 
surgiram finalmente dois artigos monográficos sobre o tema, de índole distinta, da autoria de Vital Moreira e José Domingues ${ }^{22}$. Perante tamanha lacuna bibliográfica e científica, é possivel que ainda estejam por descobrir outros pareceres que há duzentos anos -no mês de outubro de 1820-foram enviados à Junta Provisional Preparatória das Cortes com o intuito de contribuir para uma rápida e eficiente formação das Cortes, numa manifestação precoce e ímpar de política participativa.

Até à data, conseguimos localizar mais cinco pareceres originais inéditos, das seguintes autorias: António de Almeida ${ }^{23}$, António José Vaz Velho ${ }^{24}$, Bernardo José de Abrantes e Castro ${ }^{25}$, um anónimo, que assina como "um provinciano, amigo do rei e da Pátria" 26 e outro anónimo de um franciscano assistente em Amarante $^{27}$; a que acresce o esboço de um parecer incompleto, também anónimo 28 .

Neste artigo vamos limitar-nos ao parecer de António de Almeida, sob a custódia atual da Biblioteca Pública Municipal do Porto, preservado juntamente com outros manuscritos originais do mesmo autor, que agora se junta e vai acrescer ao pecúlio documental dos aludidos pareceres até à data conhecidos (embora alguns apenas de forma resumida e parcial), a maioria já vertidos em letra de imprensa.

Trata-se de um parecer sui generis, datado de 23 de outubro de 1820, em Penafiel, que propunha à Junta Preparatória das Cortes uma representação política nacional de indole corporativista. Esta visão, como veremos de seguida, extremou-se completamente dos parâmetros gerais e das correntes politicas da época, debatidas entre conservadores e inovadores, em que assentava a questão da representação nacional e da formação das Cortes. Naquele tempo, invocando as palavras de Joaquim de Carvalho:

"Os timoratos e conservadores queriam umas Cortes de harmonia com a constituição tradicional das ordens do Estado, isto é, umas Cortes nas quais os procuradores se repartissem, segundo as suas qualidades, pelas ordens ou braços da nobreza, do clero e do povo; os inovadores, pelo contrário, propugnavam umas Cortes provindas da soberania nacional e do sufrágio individual, nas quais os deputados, constituindo uma única assembleia, tivessem a mesma situação jurídica e usufruissem os mesmos direitos de voto e de deliberação"29

\footnotetext{
${ }^{22}$ Vital Moreira e José Domingues, “A primeira polémica política da Revolução de 1820”, in História: Jornal de Notícias 13, abril de 2018, pp. 44-53; José Domingues e Vital MoreIRA, "Nas Origens do Constitucionalismo em Portugal", op. cit., pp. 1-39.

${ }^{23}$ Porto, BPMP - Ms. 1757, n. ${ }^{\circ} 10$.

${ }^{24}$ Lisboa, ACL - Manuscritos da Série Azul, n. ${ }^{\circ} 1532$.

${ }^{25}$ Lisboa, FDUL - Ms. Av. LXVII, n. ${ }^{\circ}$.

${ }^{26}$ Lisboa, BNP - Cod. 10454//12.

${ }^{27}$ Lisboa, BNP - Cod. 10454//8.

${ }^{28}$ Lisboa, BNP - Cod. 10454//10.

${ }^{29}$ Joaquim de CARVALHO, “A Corrente Regeneradora (Século XIX)”, op. cit., p. 65.
} 
Foi o manuscrito autógrafo de António de Almeida, atualmente arquivado na Biblioteca Pública Municipal do Porto, que serviu de mote ao presente artigo e que passamos a analisar, começando pelos dados biográficos que conseguimos coligir sobre o autor e debruçando-nos, de seguida, sobre o conteúdo do parecer, cujo texto integral publicamos em anexo, concluímos com a sua apreciação critica.

\section{DADOS BIOGRÁFICOS SOBRE O AUTOR DO PARECER}

António de Almeida, filho do barbeiro Caetano de Almeida e de sua mulher Francisca Teresa da Piedade, moradores no Largo da Feira, cidade de Coimbra, foi batizado na freguesia de S. João de Almedina da mesma cidade, no dia três de agosto de $1767^{30}$. Faleceu aos sessenta e um anos de idade, na cidade de Penafiel, no dia treze de maio de 1839 e foi sepultado no dia quinze, na igreja de Nossa Senhora da Conceição ${ }^{31}$. Nesta última passou quarenta e oito anos da sua vida, tendo casado em 1793 com uma senhora da alta sociedade pinafidelense, D. Mariana Joaquina Pereira Beça Veloso de Barbosa e Almeida, da qual teve "uma vasta prole", que morreu quase toda "em tenra idade" 32 .

Em Penafiel exerceu as funções de médico do partido da câmara e da misericórdia, foi eleito vereador da primeira câmara constitucional em 18221823, presidente da câmara municipal em 1834-1835 (depois da restauração do constitucionalismo) e vereador em 1836; ao nível da comarca de Penafiel foi comissário delegado da junta do protomedicato e membro da comissão de exame e melhoramento das cadeias. Além disso, foi politico, escritor, historiador, sócio correspondente da Instituição Vacínica, sócio da Academia Real das Ciências de Lisboa e da Sociedade das Ciências Médicas e de Literatura da cidade do Porto ${ }^{33}$.

Entrou para a Universidade de Coimbra em 1781, com apenas catorze anos de idade, alcançou o grau de bacharel em Filosofia (1781-1784), cursou Matemática (1782-1784) e formou-se em Medicina (1785-1789) ${ }^{34}$. A 31 de julho de 1790 foi-lhe passada, pelo reitor da Universidade de Coimbra, D. Francisco Rafael de Castro, a carta de formatura em Medicina, que, conforme a Lei do Reino e os Estatutos da Universidade, o habilitava a usar de suas letras livremente em qualquer parte:

"havendo conseguido o grau de bacharel na Faculdade de Medicina, como mostrará por sua carta, e havendo continuado mais um ano de frequência e ouvido as Lições de Prática Médica e Cirurgia, da sua obrigação, conforme os novos Estatutos desta Universidade, com a prova dele se habilitou para fazer, como fez com efeito, a sua formatura por vinte dias continuos, desde o dia 10 até ao dia 30 de julho de 1790, no qual exame

\footnotetext{
${ }^{30}$ Coimbra, AU - IV-1 a D-5-2-2, fls. 81-81v.

${ }^{31}$ Porto, AD - Paróquia de Penafiel, Livro de Registo de Óbitos 1834-1859 (K/13/3-714.1), fl. 17 [Disponível em: https://pesquisa.adporto.arquivos.pt/details?id=752990 (consultado no dia 6 de setembro de 2019).

32 Sofia FERnANDES, "António de Almeida: De partidista a presidente de Câmara", in Políticas Sociais em Perspetiva (séculos XVII-XX), Braga, Universidade do Minho, Lab2PT, 2017, pp. 109-123 (115).

${ }^{33}$ Sofia FERNANDES, “António de Almeida: De partidista a presidente de Câmara”, op. cit., p. 109.

${ }^{34}$ Coimbra, AU - Índice de Alunos da Universidade de Coimbra.
} 
praticou o curativo de diferentes doenças no Hospital da mesma Universidade, perante todos os professores da Faculdade, e deliberando estes em congregação sobre o seu merecimento, distribuidos e regulados os votos, foi por todos aprovado Nemine Discrepante"35.

Inocêncio considerou-o "um escritor laborioso e inteligente (...) um homem estudioso e investigador, não só nas matérias da sua profissão, mas muito mais nos ramos de história, arqueologia e filosofia portuguesa", que tinha publicado apenas uma obra em formato de livro - História da febre que grassou em Penafiel nos anos de 1791 e 1792-, mas, em contrapartida, tinha publicado vários trabalhos dispersos em periódicos do jaez das Memórias da Academia Real das Ciência, Jornal Enciclopédico, Jornal de Coimbra, Anais da Sociedade Literária Portuense e Revista Literária do Porto ${ }^{36}$. Atribuiu-1he as publicações seguintes:

- História da febre que grassou em Penafiel nos anos de 1791 e 1792;

- Dois artigos sobre o sistema preferivel na ortografia portuguesa, defendendo a opinião de que a escrita deve ser em tudo conforme à pronúncia;

- Coleção da maior parte dos estatutos, leis, alvarás, decretos e ordens relativas a medicina e cirurgia para servirem como documentos à história da ciência de curar em Portugal;

- Reflexões acerca do monumento que existe na freguesia da Ermida do concelho de Penafiel;

- Vocabulário português das plantas com os nomes latinos e sistemáticos correspondentes, bem como as suas etimologias;

- Anais vacínicos de Portugal ou Memória Cronológica da vacinação em Portugal, desce a sua introdução até ao estabelecimento da Instituição Vacinica da Academia Real das Ciências;

- Quadros bibliográficos das obras publicadas em Portugal desde 1800 até 1820;

- Descrição histórica e topográfica da cidade de Penafiel;

- Exame comparativo das crónicas portuguesas relativamente ao governo do Senhor conde D. Henrique;

- Memória polémica acerca da verdade da jornada de Egas Moniz a Toledo;

- Erros histórico-cronológicos de Fr. Bernardo de Brito na Crónica de Cister, corretos em 1834;

- Memória sobre a legitimidade ou ilegitimidade da Senhora D. Teresa, mulher do conde D. Henrique;

- Memória médico-histórico-cosmográfica acerca do abuso de tomar bichas pelo Santiago no rio Sousa;

- Série dos bispos do Porto e daquelas pessoas a quem falsamente se prodigalizou o título de bispo na mesma cidade, no periodo do primeiro século da Igreja até ao fim do sétimo século.

\footnotetext{
${ }^{35}$ Coimbra, AU - IV-2 ${ }^{\mathrm{a} D}-12-2-24$.

${ }^{36}$ Inocêncio Francisco da Silva, Dicionário Bibliográfico Português, Tomo I, Lisboa, Imprensa Nacional, 1858, pp. 81-83.
} 
A comprovar a sua qualidade de correspondente da Academia das Ciências de Lisboa, na biblioteca/arquivo desta instituição guardam-se vários manuscritos dos seus trabalhos, mesmo dos que não chegaram a ser impressos e, por isso, nem sequer constam da listagem de Inocêncio:

- Descrição Histórica, Física e Económica da Cidade de Penafiel (ACL, Manuscritos da Série Azul, n. ${ }^{\circ}$ 343).

- Noticia de Duas Fontes Minerais (ACL, Manuscritos da Série Azul, n. ${ }^{\circ}$ 377 / 16).

- Dissertatio inqua botanicas utilitas generatim consideratur (ACL, Manuscritos da Série Azul, n. $\left.{ }^{\circ} 377 / 20\right)$.

- Discurso [sobre Medicina] que oferece a esta Sábia Academia (ACL, Manuscritos da Série Azul, n. $\left.{ }^{\circ} 377 / 25\right)$.

- Discurso que sobre os abusos médicos observados na cidade de Penafiel oferece a esta Ilustre e Sábia Academia António de Almeida, Bacharel em Filosofia e Médico da mesma Cidade (ACL, Manuscritos da Série Azul, n. $\left.{ }^{\circ} 377 / 26\right)$.

- Ensaio crítico, no qual pretende mostrar ser insuficiente para o descobrimento das virtudes medicinais dos corpos da natureza o conhecimento quimico dos principios constituintes dos mesmos corpos (ACL, Manuscritos da Série Azul, n. ${ }^{\circ} 377 / 27$ ).

- Memória acerca da cura preservativa das bexigas (ACL, Manuscritos da Série Azul, n. ${ }^{\circ} 377 / 28$ e 29).

No códice da Biblioteca Pública Municipal do Porto (Ms. 1757), juntamente com o parecer sobre a convocação das Cortes, foram encadernados outros trabalhos manuscritos do seu punho, alguns dos quais foram enviados às Cortes Constituintes de 1821-1822:

- Memória oferecida às Cortes constituintes quando se tratou da convocação das Cortes ordinárias;

- Plano estatístico-genealógico de Portugal37;

- Apontamentos para a reforma disciplina da Universidade de Coimbra ${ }^{38}$;

- Plano de reforma no processo dos tabeliães dirigido à maior firmeza dos contratos para acautelar as fraudes que neles se podem perpetrar e à conservação perpétua dos mesmos ${ }^{39}$;

- Memória em que se prescrevem os meios de poder o Governo obter com maior exatidão mapas estatísticos do reino;

- Discursos enviados a periódicos.

\footnotetext{
${ }^{37}$ Foi apresentado pelo deputado Peixoto na sessão das Cortes de 7 de julho de 1821 -Diário das Cortes Gerais e Extraordinárias da Nação Portuguesa, n. ${ }^{\circ}$ 121, Lisboa, Imprensa Régia, p. 1464-.

${ }^{38}$ Estes "apontamentos" foram apresentados na sessão das Cortes Constituintes de 5 de março de 1822 e distribuídos à Comissão de Instrução Pública -Cf. Diário das Cortes Gerais e Extraordinárias da Nação Portuguesa, n. ${ }^{\circ} 28$, Lisboa, $^{2}$ Imprensa Régia, p. 360-. A memória original conserva-se em Lisboa, Arquivo Histórico Parlamentar - Secção I/II, cx. 48, mç. 27 , doc. 82 .

39 Este "plano" foi apresentado na sessão das Cortes Constituintes de 24 de novembro de 1821 e distribuído à Comissão de Justiça Civil -Cf. Diário das Cortes Gerais e Extraordinárias da Nação Portuguesa, n. ${ }^{\circ}$ 234, Lisboa, Imprensa Régia, p. 3206-. O manuscrito original conserva-se em Lisboa, no Arquivo Histórico Parlamentar e foi publicado em Maria Halpern PereIRA (Dir.), A Crise do Antigo Regime e as Cortes Constituintes de 1821-1822, Vol. V: Benedicta Maria Duque VIEIRA, A Justiça Civil na Transição para o Estado Liberal: Estudo e Documentos, Lisboa, Centro de Estudos de História Contemporânea / ISCTE, edições João Sá da Costa, 1992, pp. 92-96.
} 
António de Almeida foi um político bastante ativo, durante o período constituinte de 1821-1822, tendo enviado várias memórias ao Magno Congresso. Para além das suprarreferidas, enviou ainda uma "Memória sobre a injusta sucessão e herança dos bens dos prazos, bem como algumas reflexões sobre testamentos", datada de 3 de setembro de 182140; e outra "sobre a extinção da mendicidade viciosa", que foi remetida à Comissão de Saúde Pública na sessão das Cortes de 13 de outubro de $1821^{41}$.

Centremos agora a atenção no trabalho, até à data completamente desconhecido, que constitui o objeto do presente estudo -o "Projeto de Representação Nacional"-. Tudo começou no dia em que António de Almeida recebeu a circular da Junta Preparatória das Cortes, com data de 9 de outubro de 1820, acompanhada da portaria da mesma Junta de 6 de outubro de 1820 . Nesta portaria, a Junta tinha determinado consultar a opinião pública mais esclarecida sobre o melhor e mais eficaz método de representação nacional em Cortes $^{42}$; na circular, convidava-o diretamente a ele -António de Almeida- para apresentar a sua opinião sobre tão delicado assunto. Algumas destas circulares "foram assinadas pelo secretário Filipe Ferreira, outras pelo secretário barão de Molelos. O número das que se expediram chegou a duas mil e duzentas ${ }^{43}$, pois compreendeu, não só todas as pessoas de quem havia representação de sua literatura, mas ainda a todos os fidalgos, dignidades, ministros e empregados em postos eminentes" 44 . António de Almeida teve o cuidado de apensar ao seu parecer as referidas portaria e circular (impressas) que lhe tinham sido dirigidas pela Junta Preparatória das Cortes. Isso permite-nos reproduzir aqui a circular pessoal que o convidou a apresentar a sua douta opinião, colocando entre parêntesis o preenchimento que foi feito à mão, no próprio impresso, pelo escrivão da Junta Preparatória das Cortes, Filipe Ferreira de Araújo e Castro:

\footnotetext{
${ }^{40}$ Acusada a receção na sessão das Cortes de 10 de setembro de 1821 e remetida à Comissão de Justiça Civil Diário das Cortes Gerais e Extraordinárias da Nação Portuguesa, n. ${ }^{\circ}$ 172, Lisboa, Imprensa Régia, p. $2206-$. Publicado em Benedicta Maria Duque VIEIRA, A Justiça Civil na Transição para o Estado Liberal, op. cit., pp. 132135 .

${ }^{41}$ Diário das Cortes Gerais e Extraordinárias da Nação Portuguesa, n. ${ }^{0}$ 199, Lisboa, Imprensa Régia, p. 2635.

${ }^{42}$ Lisboa, IAN/TT - Ministérios dos Negócios Eclesiásticos e de Justiça, mç. 105, doc. 2, fl. 126 (impresso avulso); Gazeta de Lisboa, n. ${ }^{\circ}$ 242, sábado 7 de outubro de 1820; Génio Constitucional, n. ${ }^{\circ}$ 9, quarta-feira 11 de outubro de 1820; Hipólito José da CostA, Correio Braziliense ou Armazem Literario, n. ${ }^{\circ}$ 149, vol. 25, outubro de 1820, Londres, Impresso por R. Greenlaw, p. 415; Clemente José dos SANTos, Documentos para a História das Cortes Gerais da Nação Portuguesa, coordenação autorizada pela Camara dos Senhores Deputados, Tomo I: 1820-1825, Lisboa, Imprensa Nacional, 1883, p. 76; Cecília HonÓRIO, Manuel Fernandes Tomás 1771-1822, Lisboa, Assembleia da República, 2009, p. 57, nota 14; José Domingues e Vital MoreIRA, "Nas Origens do Constitucionalismo em Portugal”, op. cit., pp. 1-39.
}

${ }^{43}$ Apesar de muito elevado para a época, este número é confirmado no parecer de José Joaquim Ferreira de Moura, quando se refere ao "programa que circularmente se transmitiu, espalhou e se difundiu pelo considerável número de mais de duas mil pessoas" -cf. Adriano do NASCIMENTO - A Revolução de 1820 (documentos inéditos), Coimbra, 1962 , p. 31-.

${ }^{44}$ Registo do Expediente da Junta Provisional Preparatória das Cortes, Lisboa, IAN/TT - Ministérios dos Negócios Eclesiásticos e de Justiça, mç. 105, doc. 2, fls. 132. 
"A Junta Provisional Preparatória das Cortes, tomando em particular consideração as luzes e patriotismo de $V$. (m), transmite-lhe o impresso que agora manda publicar a respeito da convocação das Cortes e espera que $V$. (m), ainda antes do prazo ali estabelecido, sendo possivel, comunicará as noções que the ocorrerem sobre tão importante objeto.

Deus guarde V. (m). Lisboa, (9) de outubro de 1820.//

(Filipe Ferreira de Araújo e Castro

Para António de Almeida)"45

António de Almeida respondeu atempadamente ao apelo da Junta das Cortes, cumprindo o prazo dos "vinte dias" que estava pré-estabelecido na portaria de 6 de outubro. Efetivamente, em menos de duas semanas, no dia 23 de outubro de 1820, em Penafiel, concluía o seu parecer, que de imediato deve ter enviado para Lisboa, ao cuidado do mesmo escrivão que, no dia 9 de outubro, lhe tinha remetido a portaria e a circular convocatória, Filipe Ferreira de Araújo e Castro.

\section{CONTEÚDO DO PARECER}

\subsection{Restrições aos direitos politicos}

A abrir o seu arrazoado, antes de passar à descrição do processo de eleição dos deputados às novas Cortes, António de Almeida enumerou uns "principios gerais" que, prima facie, vaticinavam um sistema democrático de representação politica segundo os cânones liberais: reconhecimento amplo da cidadania individual, sufrágio universal, voto obrigatório -com o registo escrito dos faltosos, mas sem determinar a sanção que lhe era aplicável- e data prévia dos atos eleitorais -convocação das assembleias primárias ou congressos eleitorais com antecedência minima de oito dias-.

Não obstante, estabeleceu limites de idade elevados para votar e para ser eleito nas eleições primárias e um limite ainda mais elevado para ser deputado ou seja, para votar nas assembleias primárias: vinte anos; para ser eleito nessas eleições: trinta anos; e para ser eleito deputado: quarenta anos-, assim como alguns requisitos capacitários -para ser eleitor: possuir caráter de prudência e zelo do serviço público; e para ser deputado: ser religioso, prudente e sábio, não só nos conhecimentos privativos à sua classe, mas também nos mais ramos da economia pública-.

Sem embargo, nesta época, mesmo na versão progressista adotada pelo vintismo entre nós, a cidadania ampla e o "sufrágio universal" estavam muito longe de implicar uma participação na vida política de todos os cidadãos maiores de idade, estando, desde logo completamente excluído o sufrágio feminino. Por isso, quando muito, seria um "sufrágio universal masculino", não podendo considerar-se que o sistema de representação politica fosse inteiramente democrático. Acresce que, nos domínios ultramarinos, também seriam excluídos de votar os escravos e as pessoas de determinadas raças. Um caso assaz curioso e ainda por resolver em toda a sua dimensão foi o dos pardos ou

\footnotetext{
${ }^{45}$ Porto, BPMP - Ms. 1757, n. ${ }^{\text {}} 10$.
} 
afrodescendentes no Brasil (que nem sequer eram considerados cidadãos). Sendo certo que, em 1821, nas províncias da Bahia e Minas Gerais, pelo menos, "alargou-se substancialmente a base eleitoral, através do reconhecimento da capacidade eleitoral à população parda"46. Posteriormente, as Cortes Constituintes de 1821/22 procederam a uma inclusão política dos afrodescendentes libertos e livres, atribuindo a cidadania portuguesa aos "escravos que alcançarem carta de alforria" (Constituição de 1822 , art. $\left.^{\circ} 21^{\circ}\right)^{47}$.

Ora, no caso do nosso autor, para além dos exigentes requisitos etários, há manifestas restrições à generalidade e igualdade do sufrágio, visto que, como veremos abaixo, ficavam privados de representação todos os cidadãos que não entrassem numa das categorias selecionadas para gozarem de representação particular e gozavam de sufrágio múltiplo os que integrassem mais do que uma das categorias.

\subsection{Representação de indole corporativista}

Para chegar ao método mais adequado para se determinar a representação política para as próximas Cortes, António de Almeida partiu da metáfora do "corpo político", que comparava a Nação ao corpo humano ("corpo físico"); a esta opção não terá sido totalmente indiferente a sua formação académica e a prática profissional na área da medicina. O pressuposto de um "corpo político" levou-o a alvitrar uma representação politica de indole corporativista, segundo a qual os deputados seriam eleitos pelas seguintes dez "ordens" ou corporações, merecedoras de "representação particular": proprietários de prédios rústicos e urbanos, cidades e vilas "consideráveis", classe mercantil dos comerciantes e fabricantes, clero secular, clero regular, Universidade de Coimbra, Academia Real das Ciências de Lisboa, corpo militar, tribunais e Companhia dos Vinhos do Alto Douro.

Este método seria preferivel ao que ele designa por "representação numérica", querendo-se referir, obviamente, ao método eleitoral estabelecido na Constituição de Cádis, que pressupunha a eleição dos deputados pelo conjunto dos cidadãos (se bem que num procedimento eleitoral com vários degraus), numa base individual, sem qualquer classificação por estados, classes ou corporações, de acordo com os cânones individualistas do liberalismo politico.

\subsection{As categorias representadas}

\subsubsection{Representação dos proprietários}

Não é por acaso que o autor começa pela representação dos proprietários (rurais e urbanos), que ele considera a categoria mais numerosa e, por assim dizer, a base do corpo político. A eleição dos deputados pela classe dos

46 Vital Moreira e José Domingues, “As primeiras eleições constituintes no Brasil (1821)", in Fórum Administrativo 216, Belo Horizonte, fev. 2019, p. 78.

${ }^{47}$ Cf. Luiz Geraldo SILVA, "Afrodescendentes livres e libertos e igualdade política na América portuguesa. Mudança de status, escravidão e perspectiva atlântica (1750-1840)", in Almanack. Guarulhos 11, dezembro de 2015, pp. 623-624; Ana Cristina Nogueira da Silva e João Paulo Pimenta, Portugal, uma retrospectiva: 1822 (vol. 9), Dir. Rui TAVARES, Lisboa, Público e Tinta-da-China, 2019, pp. 72-91. 
proprietários de prédios rústicos e urbanos $\left(\mathbf{\$} 4 .^{\circ}\right)$, seguindo a "divisão política em concelhos", estava prevista inicialmente em dois graus eleitorais, não sendo, portanto, uma eleição direta. Primeiramente, em assembleia primária de freguesia os cidadãos maiores de vinte anos elegiam um "eleitor" por cada freguesia; num segundo grau, os "eleitores" escolhidos pelas várias freguesias formavam o congresso eleitoral ao nivel do concelho ou município e elegiam um deputado representante e outro suplente (que só seria chamado em caso de alegado impedimento, aceite pelas Cortes, do deputado representante). Como veremos, foi necessário estabelecer um terceiro grau eleitoral, ao nivel territorial da comarca, para reduzir o excessivo número de deputados desta corporação a um número minimamente aceitável.

A convocação das eleições era feita pelo Governo, em missiva dirigida ao juiz do concelho, que, por sua vez, expedia uma carta convocatória para cada um dos párocos das freguesias (inclusive os coutos e as honras) do seu concelho, fixando o dia certo para a convocação das assembleias primárias. Depois de lida na missa conventual, esta carta deveria ser afixada no lugar do costume, para que todos pudessem tomar conhecimento.

As eleições em assembleias primárias realizavam-se num domingo, em "lugar cómodo", formando-se uma mesa eleitoral com o pároco, o juiz da igreja e um freguês que soubesse bem escrever, para servir de escrivão. O rol dos confessados da respetiva freguesia servia de "caderno do recenseamento eleitoral", para o pároco chamar os votantes e se registarem os nomes dos faltosos ${ }^{48}$; todavia, o autor não referia como se separavam os proprietários dos demais "confessados" do rol paroquial. Os votos eram registados pelo escrivão numa folha de papel, assinalando com um sinal as vezes que cada elegivel era nomeado: o mais plausivel é que o "sinal" fosse um pequeno traço vertical colocado à frente dos nomes registados e se a pessoa indicada já constasse da lista, por ter sido escolhida por um votante anterior, o escrivão limitava-se a acrescentar novo traço à frente do nome proferido. No final, ficava proclamado eleitor da freguesia o freguês que reunisse mais votos (maioria relativa).

No domingo seguinte, proceder-se-ia à reunião do congresso eleitoral municipal na própria Casa do Concelho, comparecendo perante o Senado municipal e o seu escrivão os vários eleitores das freguesias do concelho, munidos das respetivas credenciais outorgadas pelas assembleias eleitorais primárias, para elegerem um deputado representante e outro suplente. O procedimento eleitoral impunha a organização dos eleitores em três secções apartadas: para tal, o escrivão da Câmara escrevia os nomes dos eleitores em bilhetes separados, que depois de enrolados eram lançados numa urna ("escrutinio") e tirados à sorte. Cada uma das secções, por maioria dos votos,

\footnotetext{
${ }^{48} \mathrm{O}$ recenseamento eleitoral ativo em Portugal foi instituído, pela primeira vez, pela lei eleitoral de 11 de julho de 1822 (art. ${ }^{\circ} 23^{\circ}$ ), publicada em: Diário das Cortes Geraes, Extraordinarias e Constituintes da Nação Portugueza, Tomo VI, Lisboa, Imprensa Nacional, 1822, pp. 778-795 [Disponível em: http://debates.parlamento.pt/ (consultado no dia 12 de abril de 2018)]; Diário do Governo, n. ${ }^{\circ}$ 176, segunda-feira 29 de julho de 1822; Collecção das Cartas de Lei, Decretos, etc. das Cortes Geraes, Extraordinarias e Constituintes da Nação Portugueza, Coimbra, Imprensa da Universidade, 1822, pp. 309-358; Pedro Tavares de AlmEIDA, Legislação Eleitoral Portuguesa 1820-1926, Lisboa, Imprensa Nacional, 1998, pp. 31-39; Maria NAMORADO e Alexandre Sousa PINHEIRO, Legislação eleitoral portuguesa: textos históricos (1820-1974), Tomo 1, Lisboa, Comissão Nacional de Eleições, 1998, pp. 39-57. Sobre o recenseamento eleitoral em Portugal, cf. Manuel MonteIro, Do Recenseamento Eleitoral em Portugal, Coimbra, Almedina, 2012.
} 
escolheria um deputado representante e outro suplementar. Entregues as três listas pelas três secções votantes, o Senado declararia para deputados os cidadãos que obtivessem a maioria dos votos, $i$. e., aqueles que o nome constasse pelo menos em duas listas das secções. No caso de serem diferentes as três listas, o Senado mandaria "fazer escrutinio" -escrevendo os nomes em bilhetes separados, para serem lançados em urna- em relação aos três nomeados, ficando eleito deputado o primeiro que fosse extraído da urna.

Tendo em conta que, segundo a divisão administrativa vigente em 1820, a rede concelhia era composta por "cerca de 800 câmaras em todo o reino" 49 , se a corporação dos proprietários elegesse um deputado por cada concelho, isso daria um total de cerca de oitocentos deputados. Um número "assaz numeroso", reconheceu o próprio António de Almeida, que era totalmente incomportável para uma representação política nacional de um Reino com a dimensão geográfica de Portugal e com a reduzida população que nessa altura tinha. Por isso, no final do parecer, o autor fez um aditamento à representação política desta ordem ou corporação, acrescentando-lhe mais um grau eleitoral, que se processaria ao nível territorial das comarcas civis do País.

Assim, depois de concluída a eleição ao nivel concelhio, cada deputado nomeado em congresso eleitoral do seu concelho, munido do respetivo termo de eleição passado pelo Senado, deveria comparecer na Casa do Senado da respetiva cabeça da comarca, para se proceder a um novo ato eleitoral, que seria feito em presença do corregedor da comarca, do provedor, do juiz de fora e do escrivão da Câmara, depois de verificados os documentos das eleições concelhias e confirmada a identidade dos respetivos deputados-portadores e lavrado o respetivo termo da reunião do congresso eleitoral da cabeça da comarca.

Cada um dos deputados dos concelhos passava a ditar separada e oralmente o seu voto à mesa eleitoral -composta pelos três magistrados e pelo escrivão da Câmara-, que o escrivão assentava por escrito numa folha de papel, com a indicação expressa do concelho a que pertencia o nome votado. Nesta fase do procedimento, os únicos elegiveis eram os deputados concelhios presentes "porque já tinham obtido voto da Nação"-, por isso, só em cada um deles poderia recair o voto dos demais -embora nada conste no parecer, é plausivel que se proibisse a votação em nome próprio-. Os nomes dos votados eram sempre escritos por extenso, seguindo a ordem de nomeação, mesmo que fossem nomeados mais do que uma vez, sem o uso de quaisquer sinais indicativos do número de votos obtidos. Concluído o sufrágio, a pauta com o nome dos votados era assinada pelos magistrados e pelo escrivão, para depois ficar arquivada na sede da respetiva comarca. Passava-se, então, à contagem dos votos, ficando eleito aquele que obtivesse mais votos; em caso de empate, recorria-se à sorte ou "escrutinio".

A carta credencial ao deputado efetivo ou representante de toda a comarca seria adaptada às novas circunstâncias de eleição e passada em nome dos magistrados assistentes ao ato eleitoral (corregedor, provedor e juiz). António de Almeida teve o cuidado de propor os formulários para os respetivos termos e cartas credenciais ao longo do procedimento eleitoral.

\footnotetext{
${ }^{49}$ António Costa PINTo e Nuno Gonçalo MonTEIRo (coord.), História Política Contemporânea - Portugal: 18082000, Objectiva, 2019, p. 37.
} 
Com este aditamento, concluído o terceiro grau eleitoral em sede de comarca, o cômputo final dos deputados eleitos pela ordem dos proprietários de prédios rústicos e urbanos seria de quarenta e quatro efetivos e quarenta e quatro suplentes, dois deputados (um efetivo e outro suplente) por cada comarca do País: Valença, Viana, Barcelos, Braga, Guimarães, Penafiel, Porto, Bragança, Miranda, Moncorvo, Vila Real, Feira, Aveiro, Coimbra, Viseu, Trancoso, Pinhel, Linhares, Lamego, Guarda, Castelo Branco, Arganil, Lisboa, Ribatejo, Alcobaça, Alenquer, Leiria, Ourém, Santarém, Torres Vedras, Tomar, Chão de Couce, Setúbal, Avis, Beja, Crato, Elvas, Évora, Ourique, Portalegre, Vila Viçosa, Faro, Lagos e Tavira.

Nos seus resultados, esta fórmula de representação aproximava-se do sufrágio censitário, adotado pelo liberalismo conservador (por exemplo, o cartismo, entre nós $)^{50}$, com a clareza de assumir que se tratava somente da representação dos proprietários e não de uma fictícia representação da Nação. Mas a ideia de uma representação própria de um conjunto de cidadãos, qualificadas pela propriedade, afastava esta fórmula das conceções liberais da representação unitária da Nação.

\subsubsection{Representação das "cidades e vilas consideráveis"}

Às cidades e vilas "consideráveis" também era reconhecida uma representação específica, tendo o direito de elegerem, cada uma, um deputado representante e outro suplente às Cortes, salvo as duas cidades mais populosas: Lisboa, que elegia quatro deputados representantes, e o Porto, que elegia dois deputados representantes $\left(\mathbf{\$} \mathbf{5 .}^{\circ}\right)$.

O procedimento eleitoral também se realizava em dois graus eleitorais, ambos no interior dos Paços do Concelho: primeiro, elegiam-se seis eleitores do povo e seis eleitores da nobreza; depois formavam-se três secções eleitorais: cada uma com um vereador, dois eleitores da nobreza e dois eleitores do povo. $\mathrm{O}$ sorteio era feito extraindo-se os nomes de uma urna: primeiro os seis nomes (três pares) dos eleitores nobres, depois os seis nomes (três pares) dos eleitores do povo e, finalmente, os nomes dos três vereadores. A partir daqui, seguir-se-ia o procedimento eleitoral estabelecido para escolha dos deputados da classe dos proprietários.

O número de representantes das cidades e vilas consideráveis ficou em aberto, salvo o das cidades de Lisboa (4 deputados) e do Porto (2 deputados). Para apurar este número teria de se determinar quais seriam, em 1820, as "cidades $e$ vilas consideráveis". Como o parecer é silente quanto a esta condição, o único critério possivel que nos ocorre, para preencher este conceito impreciso, é o das cidades e vilas que, por foral ou privilégio real, tinham assento nas antigas Cortes, convocadas até ao final do século XVII.

Por uma listagem feita no ano de 1535 eram convocados às Cortes os seguintes noventa lugares do Reino: Vila Real, Bragança, Torre de Moncorvo, Freixo de Espada à Cinta, Miranda do Douro, Porto, Guimarães, Braga, Ponte de Lima, Viana do Castelo, Caminha, Vila Nova de Cerveira, Valença, Monção,

\footnotetext{
50 Cf. José Domingues e Vital MoreIRA, "A Representação Política no Constitucionalismo Monárquico Conservador em Portugal: o Projeto Eleitoral de 1823”, in Historia Constitucional 20, 2019, pp. 820-822 [Disponível em: http://www.historiaconstitucional.com (consultado no dia 25 de setembro de 2019)]
} 
Barcelos, Vila do Conde, Guarda, Trancoso, Viseu, Lamego, Pinhel, Castelo Rodrigo, Castelo Branco, Monsanto, Penamacor, Covilhã, Sertã, Lisboa, Santarém, Torres Novas, Coruche, Torres Vedras, Alenquer, Sintra, Leiria, Porto de Mós, Óbidos, Atouguia, Tomar, Ourém, Pombal, Penela, Abrantes, Coimbra, Montemor-o-Velho, Aveiro, Évora, Arraiolos, Montemor-o-Novo, Viana do Alentejo, Portel, Elvas, Olivença, Campo Maior, Monsaraz, Mourão, Beja, Serpa, Moura, Ourique, Santiago de Cacém, Estremoz, Borba, Veiros, Vila Viçosa, Fronteira, Cabeça de Vide, Avis, Portalegre, Castelo de Vide, Marvão, Crato, Arronches, Alter do Chão, Alegrete, Monforte, Nisa, Setúbal, Palmela, Almada, Alcácer do Sal, Alvito, Mértola, Favila, Castro Marim, Faro, Loulé, Lagos, Silves e Albufeira ${ }^{51}$.

Podemos então concluir que, caso fosse este o critério em mente de António Almeida, a representação política das cidades e vilas consideráveis seria de circa noventa e quatro deputados efetivos: quatro pela cidade de Lisboa e dois pela cidade do Porto, mais oitenta e oito deputados das demais cidades e vilas representadas.

Qualquer que fosse o seu âmbito, este critério tradicionalista de representação seletiva de certas povoações seria completamente inviável de acordo com as conceções liberais de representação política da coletividade nacional. Segundo as palavras de Borges Carneiro, "o chamamento que somente se fazia de certas vilas, excluida a maior parte delas, além de produzir rivalidades $e$ discórdias, não exprime a representação nacional e, ainda que se queira hoje estender aquele chamamento a todas as vilas que têm juizes de fora (do que não poderia prescindir-se nas atuais circunstâncias), nem assim mesmo se desempenhará a dita representação, na qual devem intervir todas as terras do Reino"52.

Além disso, a separação da votação dos nobres e plebeus na eleição dos mesmos deputados, em pé de igualdade, além de privilegiar o peso dos primeiros (cujo número era muito inferior aos segundos), ia a arrepio das próprias conceções liberais conservadoras, que distinguiam a representação dos "pares" e a do povo em duas câmaras separadas, sem participação separada de ambas na eleição da mesma câmara.

\subsubsection{Representação dos negociantes e fabricantes}

Os negociantes e fabricantes eram a segunda classe económica merecedora de representação particular em parlamento $\left(\mathbf{\$} \mathbf{6 .}^{\mathbf{0}}\right)$, a par dos proprietários. No entanto, sendo demasiado "árduo e complicado", segundo o autor, convocar assembleias primárias destas categorias profissionais em todo o Reino, os deputados desta ordem seriam eleitos somente nas principais praças nacionais: Lisboa, Porto, Coimbra, Viana do Castelo, Setúbal, Figueira da Foz e Faro, restrição que não ocorria no caso dos proprietários.

\footnotetext{
${ }^{51}$ Alguns Documentos para Servirem de Provas à Parte $1 .^{a}$ das Memórias para a História das Cortes Gerais que em Portugal se Celebraram pelos Três Estados do Reino, ordenadas no ano de 1824, Lisboa, Impressão Régia, 1828, pp. 100-105.

${ }^{52}$ Manuel Borges CARNEIRO, “Adicionamento: Reflexão sobre as presentes Cortes Extraordinarias”, in Portugal Regenerado em 1820, 3. a edição, Lisboa, Typografia Lacerdina, 1820, p. 77.
} 
O procedimento eleitoral seria idêntico ao estabelecido para a classe dos proprietários e das cidades e vilas consideráveis, com a diferença de que, logo nas assembleias primárias, cada votante elegeria quinze eleitores. Pressupõe-se que, no final, ficariam nomeados "eleitores" os quinze mais votados. Os quinze eleitores nomeados seriam lançados no "escrutínio" (arca) para serem sorteados e organizados em três secções de cinco eleitores cada. Cada secção escolheria um deputado e um suplente. No final, ficaria eleito deputado aquele que obtivesse maioria, $i$. e., que constasse em, pelo menos, duas listas apresentadas pelas três secções. Em caso de empate (cada secção ter escolhido um candidato diferente) recorria-se à sorte por "escrutinio" dos três candidatos.

Mais uma vez, o autor não refere o modo de recenseamento dos eleitores desta classe, não sendo claro também se ela abrangia os tradicionais oficios e mesteres, que desde a Idade Média se encontravam organizados nas principais cidades em corporações profissionais, as quais em Lisboa e em algumas outras cidades se achavam representadas na chamada Casa dos Vinte e Quatro, participando no governo municipal, sendo portanto uma forma incipiente de representação política corporativa.

A representação política a eleger pela corporação mercantil dos negociantes e fabricantes ficou estabelecida em sete deputados efetivos (e outros tantos suplentes), um por cada uma das praças das que eram consideradas as principais do País, o que comparava desfavoravelmente com os 44 deputados atribuídos aos proprietários fundiários, dando conta do seu pequeno peso relativo na economia dessa época em Portugal.

\subsubsection{Representação do clero secular}

Uma das inovações do parecer ora em análise consiste numa dupla representação do clero, separando o clero secular do clero regular. A escolha dos representantes do clero secular $\left(\mathbf{S} \mathbf{7 .}^{\circ}\right)$ seguia formalidades idênticas às previstas para a eleição dos representantes dos negociantes e fabricantes, realizando-se assembleias primárias apenas nas capitais dos bispados, servindo o bispo de presidente e sendo os termos competentes lavrados pelo escrivão da Câmara Eclesiástica. Tendo em conta que a representação política do clero secular seria de um deputado por diocese e estando o Reino dividido em 17 dioceses, o total de deputados efetivos às Cortes seria também de dezassete, respetivamente.

Através desta categoria, o autor recuperava a representação específica do clero nas Cortes tradicionais, agora com separação entre o clero secular e o clero regular (cfr. ponto seguinte). Só que, enquanto nas cortes tradicionais, o clero tinha a sua própria representação separada dos outros "estados", nesta proposta os representantes do clero integravam uma câmara de representação única, junto com os representantes das demais classes.

\subsubsection{Representação do clero regular}

O clero regular teria também a sua própria representação política no parlamento $\left(\mathbf{\$} \mathbf{8 .}^{\circ}\right)$. A eleição dos seus deputados seria feita em três graus eleitorais: primeiro, por ordem do prelado maior, convocava-se uma assembleia primária para que cada mosteiro elegesse os seus "eleitores"; segundo, 
congregavam-se os eleitores dos mosteiros na Casa principal da Congregação para se elegerem os respetivos "deputados", seguindo o preceituado para os representantes da ordem dos proprietários; terceiro, os nomes dos deputados apurados pelas ordens monacais eram enviados ao arcebispo de Braga e os das ordens mendicantes ao arcebispo de Évora e "cada um destes prelados, juntamente com o deão e cónego magistral do cabido, bem como com o escrivão da Câmara Eclesiástica, procederá a fazer um escrutinio (sorteio de urna) com o nome dos eleitos e aqueles dois primeiros em quem cair a sorte ficarão os deputados representantes pelo clero regular". A carta credencial para cada um dos dois deputados seria passada pelo prelado maior da respetiva ordem.

Em suma, o clero regular enviaria às Cortes o total de dois deputados efetivos: um eleito pela ordem monacal e outro pela ordem mendicante, o que comparava muito desfavoravelmente com a representação do clero regular (17 representantes).

\subsubsection{Representação da Universidade}

Passando à Universidade de Coimbra (\$ 9.) -o “berço das ciências”, como foi designada pelo autor do parecer-, a representação politica seria de um deputado representante e outro suplementar por cada faculdade e um pela escola das artes.

A eleição seria feita em dois graus: primeiro, o reitor convocava todo o corpo académico -composto pelos lentes, doutores e pelos mestres do Colégio das Artes- para, em assembleia primária, na Sala da Universidade, se elegerem, cumulativamente, os "eleitores" de todo o corpo da Universidade; segundo, esses eleitores elegeriam um deputado representante e outro suplementar de cada faculdade e um deputado (um representante e outro suplementar) pelas artes, seguindo pari passu o procedimento eleitoral estabelecido para a corporação dos negociantes e fabricantes, acima descrita.

Tendo em conta que os Estatutos Pombalinos de 1772 tinham organizado a Universidade em seis faculdades -Faculdade de Teologia, Faculdade de Leis, Faculdade de Cânones, Faculdade de Matemática, Faculdade de Filosofia e Faculdade de Medicina53-, então a representação política da Universidade às Cortes seria de sete deputados efetivos: seis pelas faculdades e um pelo Colégio das Artes.

As Cortes e a Universidade surgiram quase em simultâneo -a primeira, em meados do século XIII (1254), e a segunda, nos finais desse mesmo século (12881290)- e ambas contribuíram de forma indelével para a formação do Estado português na Idade Média. Apesar da importância da Universidade, só no ano de 1439 é que foi admitida a sua representação política nas Cortes de Lisboa. O mesmo sucedia no contexto político da Europa medieval, pois a Universidade só participava em parlamento a título excecional, $v$. g., a Universidade de Paris (1413, 1439), a Universidade de Toulouse (1419) e a Universidade de Caen (1461). Em definitivo, "the presence of learned and law men in the state bureaucracy, in the offices of the royal chancery, as well as in the council and in the cortes, who advised the royalty, show the indispensable and intrinsic coordination

\footnotetext{
${ }^{53} \mathrm{Na}$ sua génese, de acordo com a bula de Nicolau IV, datada de 9 de agosto de 1290, a Universidade portuguesa (com sede em Lisboa) era composta por quatro faculdades: Artes, Leis Canônicas, Leis Civis e Medicina.
} 
between the university and the political and bureaucratic construction of the kingdom"54.

Mais uma vez, apesar das suas credenciais históricas em relação às antigas Cortes, a representação da Universidade não era congruente com os princípios doutrinários da representação liberal, que desconhecia a representação política de instituições.

\subsubsection{Representação da Academia das Ciências}

A representação política da segunda maior instituição científica do País, a Academia Real das Ciências de Lisboa, fundada por D. Maria I em 1779, seria de dois deputados às Cortes (\$ 10.0).

A eleição seria feita na sala das sessões, com assistência do presidente e secretário, por todos os sócios que se achassem em Lisboa, bem como pelos correspondentes, conforme o que estava determinado para a corporação dos negociantes e fabricantes, com a ressalva de que os eleitores podiam escolher qualquer membro da Academia, residente em qualquer parte do País e não apenas em Lisboa.

Valem aqui as considerações precedentes sobre a representação da Universidade.

\subsubsection{Representação da magistratura}

A representação plural proposta no parecer em análise não esquecia os principais corpos especiais do Estado, a começar pela magistratura (\$ 11. $)$. Segundo o parecer de António de Almeida, cada tribunal daria dois deputados e a sua eleição e nomeação seria feita sob a presidência dos chefes de cada um desses tribunais, seguindo o procedimento eleitoral que estava prescrito para a eleição dos deputados da Academia Real das Ciências de Lisboa.

Torna-se evidente que não se poderiam incluir nesta representação política nacional todos os tribunais, pelo que o autor do parecer estaria a referir-se, muito plausivelmente, somente aos quatro tribunais régios superiores: Desembargo do Paço, Mesa da Consciência e Ordens, Casa da Suplicação e Casa da Relação do Porto. Assim sendo, a corporação da magistratura elegeria um número máximo de oito deputados efetivos às próximas Cortes.

É desnecessário sublinhar que a representação judicial nas Cortes, além de não ter precedente histórico, ia ao arrepio da separação de poderes, um dos pilares da noção liberal do Estado.

\footnotetext{
${ }^{54}$ Maria Helena da Cruz COELHo, "The university and the cortes in the construction of the kingdom of Portugal in medieval times", in Parliaments, Estates and Representation 39/2, 2019, pp. 171-183 [DOI: https://doi.org/10.1080/02606755.2019.1603426].
} 


\subsubsection{Representação do exército}

A representação política do corpo militar seria de seis deputados: dois pela infantaria, um pela cavalaria, um pela artilharia e dois pelas milicias $\left(\mathbf{\$} 12 .^{\circ}\right)$.

O processo eleitoral estava dividido em dois graus, sem eleições primárias, considerando-se eleitores todos os oficiais presentes: primeiro, na presença do comandante de cada corpo, eram lançados os nomes dos oficiais presentes à urna de onde eram extraídos divididos em três secções (tal como estava previsto para a eleição dos deputados das classes dos proprietários, das cidades e vilas consideráveis, dos negociantes e fabricantes...) e cada uma delas faria a eleição dos deputados escolhidos para todo o corpo da sua arma, conforme estabelecido nos n. os $9^{\circ}$ e $10^{\circ}$ para a eleição dos deputados dos proprietários; segundo, mandar-se-ia a cópia do termo de nomeação ao comandante em chefe de todo o exército, o qual, na presença dos seus ajudantes-generais e do seu secretário, procederia ao "escrutinio" (sorteio em urna) de todos os nomeados para cada arma e aquele primeiro em quem recaísse a sorte ficaria deputado representante pelo corpo militar, seguindo-se no mais o estabelecido nos n. ${ }^{\circ} 11^{\circ}, 12^{\circ}, 13^{\circ}$ e $14^{\circ}$ para eleição dos deputados dos proprietários.

Desnecessário se torna sublinhar que uma representação própria dos militares, além de inovadora ao abrigo da conceção tradicional das Cortes, também era alheia às noções da representação liberal, baseada na representação unitária de toda a Nação e na separação entre o Estado e a Nação, não podendo um corpo do Estado estar integrado, como tal, na representação nacional.

\subsubsection{Representação da Companhia dos Vinhos do Alto Douro}

Por último, voltando à representação dos interesses económicos, vinha a representação política da Companhia dos Vinhos do Alto Douro (\$ 13.). António de Almeida entendeu que esta instituição, criada pelo Marquês de Pombal em 1756 e dotada de poderes públicos de regulação do vinho do Porto, deveria ter representação parlamentar própria, uma vez que a considerava um verdadeiro "banco nacional", tanto pela sua importância para a economia interna do Reino, como pelas exportações para os territórios de além-mar e nações estrangeiras.

A eleição dos deputados às Cortes seria feita pelos atuais e anteriores "deputados" da Companhia (ou seja, os representantes dos viticultores do Douro), que, na qualidade de eleitores primários, eram organizados "por escrutínio" (sorteio em urna) em três secções, seguindo-se, depois, os trâmites previstos para a representação política da Academia Real das Ciências de Lisboa. Deduzimos, por isso, que, à semelhança da dita Academia das Ciências, a Companhia dos Vinhos do Alto Douro elegia dois deputados efetivos às Cortes.

\subsection{Composição das Cortes e estatuto dos deputados}

A composição das futuras Cortes Extraordinárias Constituintes, segundo o Projeto de Representação Nacional de António de Almeida, compreenderia um total de cerca de 187 deputados, que seriam distribuídos pelas seguintes ordens ou corporações, como vimos: 


\section{Representação politica por corporação}

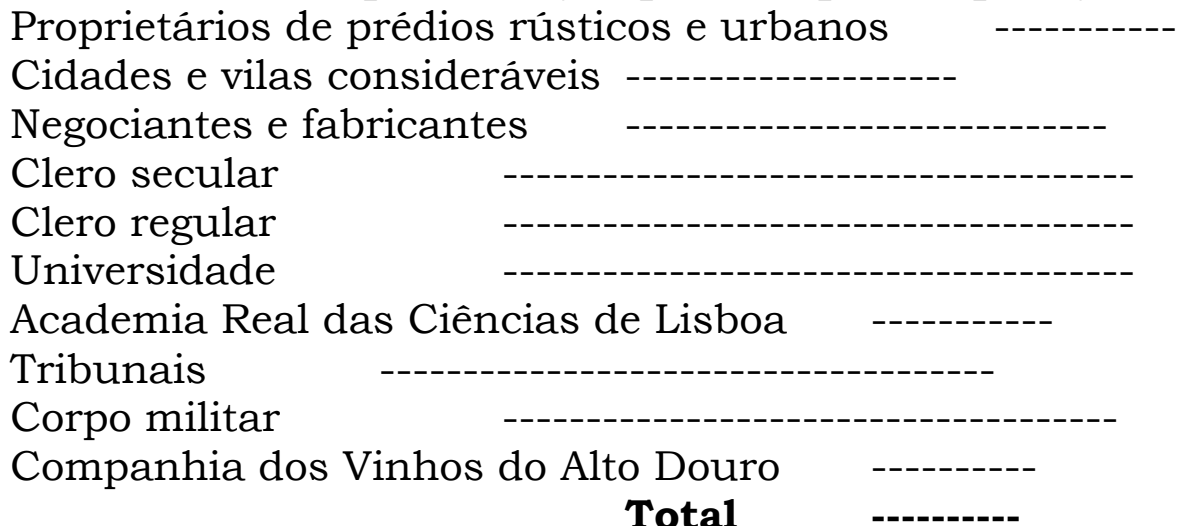

44 deputados.

94 deputados.

7 deputados.

17 deputados.

2 deputados.

7 deputados.

2 deputados.

8 deputados.

6 deputados.

2 deputados.

187 deputados.

Quanto a esta repartição é de notar o excesso da representação dos proprietários (quase $1 / 4$ dos deputados), quando comparada com a da classe mercantil, e mesmo com a representação dos corpos militar e judicial, bem como a ampla representação do clero (quase 1/10). A representação "territorial" das cidades e vilas alcançava somente metade da composição da câmara.

A finalizar o parecer aqui em exame, António Almeida teceu umas "observações gerais" que consubstanciam normas e princípios próprios de um incipiente estatuto dos deputados.

Assim, quanto à duração do mandato, o autor propunha uma legislatura de três anos, mas com renovação anual de um terço dos mandatos, o que supunha eleições todos os anos. Para esse efeito, os deputados a renovar seriam selecionados por sorteio de entre os representantes da sua classe. A ideia da renovação parcial por terços provinha possivelmente do senado dos Estados Unidos, onde a renovação se faz, porém, a cada dois anos.

Quanto a outros aspetos do estatuto dos deputados, António Almeida propunha duas importantes regras: (i) pagamento de uma "contribuição decente $e$ proporcional" aos deputados, a expensas das corporações que os elegessem (e não do próprio parlamento); (ii) igualdade dos deputados no seio do próprio parlamento, determinando que "o seu assento na sala das sessões ou em qualquer parte aonde aparecerem em corpo de representação será sem precedência ou separação". Implicitamente, as votações nas Cortes seriam feitas por contagem dos deputados e não por corporação; embora eleitos pelas corporações respetivas, os deputados formavam um corpo único, contrariamente ao que sucedia nas Cortes tradicionais.

Especial atenção dedicou o autor do parecer à indumentária dos deputados, começando pela uniformidade de vestuário para todos eles, estabelecendo um traje ordinário composto de "casaca, colete, calção ou pantalonas pretas e de lã, de fábrica nacional, podendo o colete ser de seda, mas também nacional, e travão pendente do pescoço com fita de cores da Nação, uma medalha alusiva ao emprego". Para os dias de grande gala e de cerimónia nas Cortes -que eram as sessões de abertura e de encerramento, quando o rei viesse pessoalmente às Cortes, quando se pusesse o selo real a alguma lei e outros dias de solenidade que as Cortes determinassem- os deputados usariam uma "toga, como os desembargadores, trazendo, porém, o fato de seda com as cores da Nação e gorra ou chapéu com plumas da mesma cor e a medalha igualmente lançada ao peito, pendente do pescoço". Aqueles deputados que tivessem hábito próprio, usariam 
apenas esse traje com a referida medalha ao peito. No tempo de interregno, em que as Cortes não reuniam, os deputados não podiam trazer a medalha ao pescoço, mas apenas presa no lado esquerdo da casaca e só enquanto durasse o tempo da sua nomeação. A medalha pertencia ao corpo representado e a ele deveria ser devolvida, pelo próprio deputado, logo que cessasse o seu mandato e fossem convocadas as assembleias primárias para novas eleições.

Estas regras de indumentária visavam notoriamente assegurar a igualdade de status dos deputados, sem distinção de classe, embora respeitando os trajes próprios das funções que os deputados exerciam fora do parlamento (como militares, juizes, académicos, etc.).

\section{INCOMPATIBILIDADE COM OS PRINCÍPIOS DA REPRESENTAÇÃO LIBERAL}

O debate sobre a convocação das cortes constituintes após a Revolução Liberal em Portugal passou por duas questões distintas: (i) uma, sobre a opção entre convocar as cortes tradicionais, com representação separada dos três "estados", ou convocar eleições para umas Cortes de representação unitária do Nação, compostas por deputados eleitos pelos cidadãos, sem distinção de classe.; (ii) outra, sobre o modo de eleger os deputados às Cortes, uma vez tomada a opção pela segunda alternativa citada ${ }^{55}$.

Ora, apesar de substancialmente diferente da tradicional convocação dos três estados do reino (clero, nobreza e povo), esta fórmula de representação política defendida por António de Almeida obedece a uma matriz semelhante, de representação seletiva de categorias sociais, agora acrescentando a dimensão económica, a par da do status social. Na verdade, a nobreza deixa de ter representação própria separada, compartilhando somente da representação própria das cidades e vilas, à semelhança das cortes medievais. Outra diferença notória é que, enquanto as cortes medievais compreendiam três corpos representativos distintos, que votavam separadamente, nesta proposta todos os deputados, incluindo os nobres e os membros do clero, integravam a mesma câmara representativa. Pesem embora essas diferenças, designadamente o abandono da "representação estamental" nas Cortes tradicionais, o parecer aqui em análise substitui-a por uma "representação particular" de categoriais económicas, de corpos profissionais e de instituições, que obedece à mesma filosofia da representação setorial, fragmentada, da coletividade política.

Além disso, a proposta de representação política "funcional" de António de Almeida traduz-se em evidentes assimetrias de representação, nomeadamente em representação múltipla das mesmas pessoas e na ausência de representação de outras. Assim, por exemplo, um proprietário fundiário que também seja comerciante e que resida numa cidade "considerável", participa na eleição das Cortes nessas três categoriais, ficando triplamente representado. O mesmo se diga de um membro do clero secular que seja proprietário e resida numa cidade com direito a representação particular. Em contrapartida, um cidadão que não

\footnotetext{
55 Sobre as polémicas geradas em torno da convocação das Cortes constituintes, $c f$. José DOMINGUES e Vital MoreIRA, "Nas Origens do Constitucionalismo em Portugal”, op. cit., pp. 1-39; José DomingueS e Vital MorEIRA, "A Primeira Polémica Política da Revolução de 1820”, op. cit., pp. 44-53.
} 
seja proprietário, nem resida numa cidade com direito a representação, nem pertença a nenhuma daquelas categorias, fica excluído de qualquer representação.

Torna-se por isso evidente que esta fórmula de representação política não poderia ser acolhida no seio do movimento revolucionário de 1820, por contrariar todos os princípios do liberalismo, nomeadamente o individualismo e a cidadania individual, a igualdade da representação política, sem privilégios de nascimento ou de condição, e a representação única da coletividade nacional. Na verdade, o liberalismo traduz-se, antes de mais, no combate contra o corporativismo oriundo do Antigo Regime. Reportando-se a 1820, José Liberato Freire de Carvalho asseverou que as Cortes antigas não representariam a Nação, porque esta "nunca se deve considerar como um composto de classes, porém, como um composto de individuos. São estes, em todas as sociedades bem organizadas, os que parcialmente devem ser protegidos na propriedade de suas pessoas e bens; são estes ainda os que parcialmente concorrem com suas pessoas e fazenda para a sustentação do Estado; logo são estes, isto é, logo são os indivíduos e não as classes que podem e devem ser representados" $"$.

Do que se trata, do ponto de vista corporativista, é de substituir uma fictícia representação do "interesse da Nação", como interpretado por cada cidadão, pela "representação de interesses específicos", ou seja, os interesses económicos e sociais mais relevantes no País. Enquanto o liberalismo político assenta nos direitos politicos individuais e na representação política individual, a representação corporativista assenta na representação de grupos e nos respetivos direitos políticos.

Ora, as revoluções liberais foram tanto antiabsolutistas como anticorporativistas, incluindo a rejeição dos privilégios de grupo, tão perigosos para a liberdade individual como o poder ilimitado do Estado. Não por acaso, um dos primeiros atos da Revolução Francesa foi a extinção e a proibição de reconstituição das "guildas" e corporações profissionais, bem como dos privilégios dos "corpos intermediários" entre o Estado e os cidadãos.

Por isso, indo contra o espírito do tempo, o nosso autor não deixa de desafiar uma leitura simplista da Revolução Liberal. Por um lado, embora claramente influenciado pelas ideias corporativas medievais, não é possivel identificar as influências doutrinárias específicas colhidas pelo autor, ao defendê-las, com inovações notórias, em pleno século XIX, no contexto de uma Revolução Liberal, ao arrepio dos seus princípios básicos da representação unitária da Nação. Por outro lado, embora o autor, através da ideia de representação própria de categorias económicas (proprietários, comerciantes, companhia do Alto Douro), antecipe alguns traços do corporativismo económico antiliberal que vai emergir no final do século XIX e na primeira metade do século XX, o facto de este texto ter permanecido inédito não lhe permitiu influenciar esse movimento. Mas é evidente que a linguagem do autor, por exemplo, quando se refere à necessidade de representação das "partes constituintes da Nação", evoca diretamente a

\footnotetext{
${ }^{56}$ José Liberato Freire de CARVALHO, Ensaio Histórico-Político, op. cit., pp. 241-242.
} 
linguagem da Constituição de 1933 sobre a representação dos "elementos estruturais da Nação" na conceção corporativista do chamado Estado Novo57.

Por tudo isto, esta proposta de representação politica de base corporativa aparece como uma manifestação político-doutrinária que, embora contra o espírito do tempo, testemunha a originalidade do seu autor e a vivacidade do debate político a que deu lugar a Revolução Liberal em Portugal ${ }^{58}$.

\section{CONCLUSÃO}

Como é comummente sabido, em dezembro de 1820, as eleições dos deputados para as Cortes Extraordinárias e Constituintes seguiram quase literalmente o capítulo eleitoral da Constituição espanhola de Cádis (1812), transposto e adaptado para o reino de Portugal pelas Instruções eleitorais de 22 de novembro de 1820. Esta solução legal, imposta após a Martinhada (11 de novembro de 1820), acabou por sepultar no cemitério político a esmagadora maioria dos pareceres que, em resposta à "consulta popular" de 6 de outubro, tinham sido remetidos à Junta Provisional Preparatória das Cortes.

Escaparam ao esquecimento apenas aqueles que ainda viram a luz da imprensa nesse ditoso ano de 1820 -da autoria de José Agostinho de Macedo, José Teotónio Canuto de Forjó, Francisco José de Almeida e Manuel Borges Carneiro- e o registo parcial do parecer da Academia das Ciências de Lisboa, legado pelas coevas memórias de Aragão Morato, que foram publicadas quase cem anos depois de concluídas. Entretanto, como vimos, na segunda metade do século XX, foram resgatados aos arquivos sete pareceres manuscritos inéditos (um deles truncado) e muito recentemente se desempoeirou o parecer de José Joaquim Ferreira Gordo. A que acrescem, como se viu acima, os documentos inéditos, suprarreferidos, o parecer de António José Vaz Velho e o de Bernardo José de Abrantes e Castro, dois pareceres anónimos e um esboço, também anónimo.

Estes textos constituem um manancial de valor incalculável, que espelham o nivel da cultura politica e constitucional do País, nesse preciso momento do ano de 1820. Cada um desses pareceres conhecidos, bem como aqueles que venham a ser descobertos no futuro, contribui para uma página única e incontornável da história da representação política e do parlamento em Portugal, onde começou a ser gravada a passagem das Cortes antigas para o Parlamento moderno. Uma vez que se trata de opiniões prestadas de uma forma quase espontânea por cidadãos interessados ou por entidades coletivas, num limite de tempo muito apertado (vinte dias) e livres do espartilho que geralmente condiciona as decisões politicas oficiais, estas são as mais genuínas manifestações da liberdade de pensamento e de expressão política aberta pela Revolução Liberal e, por isso, um contributo insofismável para o estudo das ideias político-constitucionais entre nós.

57 Sobre a teoria corporativa da representação política ver, por todos, Howard WIARDA, Corporatism and Comparative Politics: The Other Great "Ism", Armonk, N.Y., 1966.

\footnotetext{
${ }^{58}$ Outro aspeto heterodoxo que importa referir neste parecer de António de Almeida é o lugar conferido ao sorteio (“escrutínio"), em vez da votação, no procedimento de seleção dos deputados de várias da corporações e instituições representadas. Embora o sorteio não fosse um método desconhecido na história da representação política -ver, por todos, Oliver Dowlen, The Political Potential of Sortition, Exeter, UK, 2008-, ele não era seguramente congruente com a filosofia liberal do "governo representativo".
} 
No entanto, o panorama bibliográfico continua desolador e é bastante provável que existam mais pareceres inéditos preservados em arquivos públicos e particulares, que o tempo ainda não conseguiu apagar, como este da autoria de António de Almeida, que aqui se publica para memória futura.

$\mathrm{Na}$ realidade, os pareceres conhecidos até à data estão muito longe das mais de duas mil circulares (impressas) que foram expedidas pela Junta Preparatória das Cortes e que circularam por todo o território nacional. Por outro lado, por falta de atas, sabe-se muito pouco sobre os trabalhos desenvolvidos no seio da Junta Preparatória das Cortes, quanto ao peso que estes pareceres tiveram na formação das Instruções eleitorais que culminaram este processo, tanto nas de 31 de outubro (que foram revogadas após a Martinhada) como nas de 22 de novembro de 1820 (que foram efetivamente aplicadas); bem como na escolha da sede das primeiras Cortes Gerais Extraordinárias Constituintes (1821/22) -a sala da livraria do Convento das Necessidades, em Lisboa-, que viria a ser também a casa das sucessoras Cortes Gerais Ordinárias (1822/23). 


\section{Anexo Documental}

1820.outubro.24 (Penafiel) - Parecer do médico António de Almeida sobre a melhor forma de se convocarem as Cortes Constituintes, dando resposta a uma circular que the foi diretamente dirigida de Lisboa, datada do dia 9 de outubro de 1820 e assinada pelo secretário da Junta Provisional preparatória das Cortes, Filipe Ferreira de Araújo e Castro ${ }^{59}$.

Porto, BPMP - Ms. 1757, n. ${ }^{\circ} 10$.

\section{PROJETO DE UMA REPRESENTAÇÃO NACIONAL, A MAIS APROXIMADA PARA A CONVOCAÇÃO DAS}

CORTES DE PORTUGAL.

\section{Projeto da Representação Nacional}

§ 1. ${ }^{\circ}$

A Nação portuguesa deve considerar-se como uma grande massa corpórea, composta de corpos diferentes em quantidade e qualidade -por diversas classes, ordens e associações politicas-, os quais também se formam de partes mais pequenas, com diferentes e várias modificações -os cidadãos nos seus particulares estados-. Ora, assim como para se modelar o corpo fisico é preciso que ele contenha partes homogéneas, aquelas que constituem a grande massa, assim também para que as Cortes portuguesas tenham uma representação moral exata cumpre que se componham de partes constituintes da Nação, tal e qual ela é em nossos dias. Por isso, me parece mais adequado o plano que ofereço do que aquele da representação numérica, porquanto, além de ser esta sempre hipotética, não é exatamente representativa, pois conhecendo somente a qualidade genérica de cidadão, indubitavelmente ficarão por representar naquela escolha algumas partes essenciais da Nação, recaindo outras vezes a preponderância em alguma das classes sem que outras tenham quem advogue a sua causa.

\section{\$ 2. ${ }^{\circ}$}

Antes de entrar a particularizar o modo de fazer a representação nacional cumpre admitir estes principios gerais:

1. Que cidadão é todo o individuo nacional que habita dentro de nosso Reino, seja de que classe, ordem ou hierarquia for.

$\mathbf{2}^{\circ}$. Que todo o cidadão tem voto na nomeação dos eleitores, excedendo a idade de vinte anos.

$3^{\circ}$. Que não poderão ser nomeados eleitores cidadãos que tenham menos de trinta anos, devendo ter o caracter de prudência e zelo do serviço público.

$4^{\circ}$. Que para deputados deverão ser escolhidos cidadãos maiores de quarenta anos, moradores no distrito de eleição e que, à qualidade de pertencer à classe de que vai a ser representante, una aquelas de religioso, prudente $e$ sábio, não só nos conhecimentos privativos à sua classe, mas também nos mais ramos da economia pública.

$\mathbf{5}^{\circ}$. Que nenhum cidadão possa isentar-se de assistir às assembleias primárias nos dias prescritos.

6'. Que pelas autoridades competentes se deve fazer anúncio da convocação das assembleias primárias ou dos congressos eleitorais oito dias antes, não só

\footnotetext{
${ }^{59}$ Esta circular impressa, bem como a portaria da Junta Provisional Preparatória das Cortes de 6 de outubro de 1820 , constam anexas a este parecer.
} 
para todos os cidadãos ficarem cientes do dia prefixo e não poderem alegar escusa, mas também para que, por meio das suas conferências domésticas, se constituam mais aptos e decididos a preencher o fim da convocação.

$7^{\circ}$. Que os livros em que se devem lançar os autos de todas as eleições serão pagos à custa das corporações a que pertencem as eleições e conservados com responsabilidade pelos presidentes ou escrivães, nas suas respetivas classes.

\section{\$ 3.} seguintes:

Será a representação nacional composta de deputados tirados das ordens

$\mathbf{1}^{\mathbf{a}}$. Proprietários de prédios rústicos e urbanos.

$\mathbf{2}^{\mathbf{a}}$. Cidades e vilas consideráveis.

$3^{a}$. Comércio e fábricas.

$\mathbf{4}^{\mathrm{a}}$. Clero secular.

$\mathbf{5}^{\mathbf{a}}$. Clero regular.

$\mathbf{6}^{\mathbf{a}}$. Universidade.

$\mathbf{7}^{\mathbf{a}}$. Academia Real das Ciências de Lisboa.

$\mathbf{8}^{\mathbf{a}}$. Corpo militar.

$\mathbf{9}^{\mathbf{a}}$. Tribunais.

10. $\quad$ Companhia dos Vinhos do Alto Douro.

Nesta classificação se compreendem outras ordens de cidadãos que, ou não têm precisão de representação particular, ou se então fica subordinada aquelas mencionadas.

\section{$\S 4 .^{\circ}$ \\ Representação dos proprietários}

Sendo os proprietários a classe mais espalhada por todo o Reino se regulará a sua representação pela divisão politica em concelhos, para deste modo também abranger o todo da população.

Proceder-se-á, pois, na escolha pela maneira seguinte:

$\mathbf{1}^{\circ}$. Havendo o juiz do concelho recebido a participação do Governo para a eleição dos deputados proprietários expedirá, pelo escrivão da Câmara, carta de convocação de assembleias primárias aos párocos de cada freguesia do concelho, inclusive aqueles coutos e honras nele compreendidos, determinando o dia certo da convocação, a qual, sendo lida à missa conventual, se afixará no lugar do costume.

$\mathbf{2}^{\circ}$. No domingo assinalado, o pároco, depois da missa, exortará os seus fregueses sobre a responsabilidade da eleição que vão fazer.

$3^{\circ}$. Passando logo com o juiz da igreja e outro freguês que saiba bem escrever a qualquer lugar cómodo, irá chamando os fregueses pelo rol dos confessados, notando aqueles que faltarem e recebendo os nomes daqueles que cada um deles for nomeando para eleitores de freguesia, os irá o escrivão lançando numa folha de papel, notando com algum sinal as vezes que for nomeado.

$4^{\circ}$. Concluídos os votantes, contará o pároco com o juiz e escrivão o número dos votos e aquele freguês que tiver a maioria esse ficará proclamado eleitor. Os três assistentes assinarão a folha dos votos indicando o dia e lugar em que foi feita. 
5'. Haverá em cada freguesia um livro destinado para nele se lançarem os termos competentes a esta eleição, com o titulo de "Livro das Assembleias Primárias", e nele o mesmo freguês que serviu de escrivão lançará o termo do teor seguinte:

"Havendo no dia .... do mês .... do ano de .... recebido do juiz de ..... ordem para a convocação da assembleia primária da freguesia de ..... e havendo esta sido publicada e afixada no dia ..... do mês ..... do mesmo ano se procedeu no dia .... do mesmo mês e ano à nomeação do eleitor por esta freguesia, na presença de F.... abade, reitor ou cura da mesma, de F.... juiz da igreja, e de mim escrivão, abaixo assinados, na forma prescrita, e saiu nomeado eleitor à pluralidade de votos F...., morador no lugar de ..... da mesma freguesia, a quem foi intimada esta nomeação que aceitou e para testemunho assinou o presente termo aos .... de .... do ano de .... em ....”.

Seguem-se as assinaturas, declarando cada assinante a sua qualidade de pároco, de juiz, de eleitor e de escrivão.

6'. Passará o escrivão outro termo igual ao que está lançado no livro, o qual se entregará ao eleitor com o pacote dos votos e o rol dos fregueses que faltaram, com os motivos da falta, para ser entregue ao juiz do concelho no dia prescrito para a eleição dos deputados.

$\mathbf{7}^{\circ}$. Oito dias depois das assembleias primárias se apresentará na Casa do Concelho o juiz e mais oficiais e escrivão da Câmara e nela apresentarão os eleitores os documentos do $n .^{\circ} 6$ para se verificar a identidade das pessoas, cujos ficarão no arquivo, e logo pelo escrivão da Câmara se lançará num livro, que terá por título "Livro das Eleições dos Deputados Proprietários do Concelho de ....", o termo seguinte:

"Aos .... do mês de .... do ano de .... compareceram nesta Câmara F..... eleitor pela freguesia de ..... (aqui se irão nomeando todos), como verificaram pelos documentos que foram examinados por este Senado e se guardam no arquivo da mesma, sendo as próprias pessoas neles mencionadas, de que eu escrivão dou fé, pelo que o mesmo Senado deu por convocado o congresso eleitoral e mandou fazer este termo que comigo aprovaram .... em Câmara aos .... de .... do ano de ....".

Seguem-se, primeiro as assinaturas da Câmara e depois as dos eleitores declarando cada um: "eleitor pela freguesia de .....".

$\mathbf{8}^{\circ}$. Feito este termo, o juiz lhes deferirá, aos eleitores, o juramento dos Santos Evangelhos, lembrando-lhes o $n .^{\circ} 4 .^{\circ}$ do $\S 1 .^{\circ}$ e que ficam responsáveis a Deus e à Nação pelo bom ou mau acerto da eleição. E escrevendo o escrivão da Câmara os nomes de cada um dos eleitores num bilhete e enrolando-os os lançará no escrutínio, havendo-os contado, irão saindo por sua ordem, dividindo-os em três secções.

9'. Cada uma das secções se apartará para as suas mesas e aí, conferenciando amigavelmente, escolherão um deputado representante e outro deputado suplementar, o que se escreverá numa folha de papel, que será assinada por todos os eleitores de cada secção, ainda mesmo quando algum deles não convenha, pois que a maioria dos votos deve decidir, e depois entregue ao Senado. 
10. Concluida a entrega das listas, o Senado as examinará e declarará por deputados aqueles cidadãos que obtiveram maioria de votos. Caso, porém, as três listas venham com nomeações diversas, então, o Senado, à vista de todo o congresso eleitoral, mandará fazer escrutínio aos três elegidos e aquele em que cair a primeira extração ficará proclamado deputado proprietário. E logo o escrivão lançará no livro o termo seguinte:

"E logo no mesmo ato, convocado o congresso eleitoral, the foi deferido o juramento dos Santos Evangelhos para procederem na eleição do deputado representante e do deputado suplementar, pela parte dos proprietários do concelho de ..... com aquele cuidado que merece um emprego que vai ser responsável a Deus e à Nação pelo bem ou mal que se seguir das suas decisões. E sendo na forma prescrita divididos em três secções por escrutinio, resultou das suas conferências sair eleito por pluralidade de votos lou por escrutinio) F.... morador no lugar de .... freguesia de .... para deputado representante, e F.... morador em .... freguesia de .... para deputado suplementar, como consta do documento da nomeação recolhido no arquivo. $E$ para maior clareza se fez o presente termo ..... em Câmara de ..... de ..... do ano de .....".

Seguir-se-ão as assinaturas, primeiramente do Senado, depois dos eleitores, como fica dito no $n .^{\circ} 7$ deste $\S^{60}$.

11. Aprazar-se-á dia para comparecerem os dois deputados eleitos e em presença do Senado se lhes deferirá o juramento aos Santos Evangelhos de como, no exercício da sua deputação, procederão segundo as normas da religião católica apostólica romana e conforme as máximas da sã justiça, zelando o bem público em geral e aquele do concelho que o deputa em particular, do que tudo se fará termo no livro competente, que será assinado pelo Senado e pelos dois deputados designados, cada um deles à qualidade da sua deputação.

12. $\quad$ Concluido este ato, se passará ao deputado representante a sua carta credencial para as Cortes, na forma seguinte:

"O Senado da Câmara de .... fazemos saber que, havendo-se convocado as assembleias primárias das freguesias deste concelho no dia .... do mês de ..... do ano de ....., e o congresso eleitoral na Casa da Câmara desta ..... no dia .... de .... do ano de .... nele saiu nomeado por pluralidade de votos ou por escrutinio F.... morador em ..... da freguesia de ..... de idade de .....e como por esta fica constituido deputado representante proprietário do concelho de ..... se the passa a presente carta credencial para que, em nosso nome e dos povos que representa, possa, enquanto durara a sua nomeação requerer em Cortes, confirmar, desprezar e assinar tudo aquilo que for a bem e proveito da Nação e deste concelho em particular. Dada em Câmara de ..... do mês de .... do ano de .....”.

E se seguirão as assinaturas do Senado, selando-se a carta com o selo do concelho.

\footnotetext{
${ }^{60}$ Veja-se a adição no fim.
} 
13. Será o teor desta carta transcrito no mesmo livro das eleições e assinado pelo deputado, declarando em como o recebeu.

14. Caso o deputado representante não possa assistir nas Cortes, por motivo que estas aceitem, se passará carta credencial ao deputado suplementar e nela se declarará, além do mencionado no $n .^{\circ} 12$ deste $\S$, o motivo da nova carta.

\section{§ $5 .^{\circ}$ \\ Representação das cidades e vilas}

As cidades e vilas consideráveis formam uma massa de cidadãos que necessita ser representada particularmente, por isso mesmo que a sua união em população, os seus interesses e até as suas hierarquias lhes fazem contrair certas correlações, que os mais cidadãos dispersos não têm. A escolha dos seus representantes se fará pela forma seguinte:

1. $^{\circ}$ O Senado mandará afixar, nos lugares do costume, editais de convocação da nobreza e povo para que, em dia aprazado, compareçam na Casa do Concelho para se proceder na eleição dos deputados pela cidade ou vila.

$\mathbf{2}^{\circ}$. No dia determinado, juntando-se a Câmara, a nobreza e o povo, lhes fará o juiz um discurso (n. 2 do $\S 4 .^{\circ}$ ), declarando-lhes o $n .^{\circ} 3$ do $\S 2 .^{\circ}$, e logo o escrivão da Câmara, tendo à sua vista o rol da nobreza, começará a tomar os votos como $n .^{\circ} 3$ do $\S 4 .^{\circ}$, nomeando, porém, cada pessoa a seis cidadãos da sua hierarquia e, ao mesmo tempo, em outra sala, o juiz do povo com os mesteres e Casa dos Vinte e Quatro, onde os houver, ou o procurador do povo e juizes dos oficiais atuais com os juizes ou procuradores do povo dos anos antecedentes e um escrivão, que o juiz nomear, irão dando o seu voto para seis homens do povo. Estas pautas, sendo assinadas pelos escrivães e juiz do concelho e juiz ou procurador do povo atual, cada um na sua assistência, serão apresentadas ao Senado, que proclamará os eleitores como $n .^{\circ} 4^{\circ}$ do $\S$ 4. ${ }^{\circ}$, fazendo-se os termos, como no $n .^{\circ} 5^{\circ}$ e $6^{\circ}$ do mesmo $\S$, num livro que terá por titulo "Livro das Eleições dos Deputados de ....", mas não lhes passará carta, bastando somente serem avisados pelo escrivão da Câmara.

$3^{\circ}$. Congregada a Câmara e eleitores e feito o termo como $n .^{\circ} 7^{\circ}$ do $\S 4 .^{\circ}$, fará o escrivão bilhetes com os nomes de cada um dos eleitores nobres, que lançará na urna, e o mesmo com os eleitores do povo, que lançará em outra urna à parte, e fazendo o mesmo com os três vereadores, tirará por sorte um vereador, dois nobres e dois do povo. E feita as secções se procederá como nos $n .^{o s} 7^{\circ} .8^{\circ}, 9^{\circ}, 10^{\circ}, 11^{\circ}, 12^{\circ}, 13^{\circ}$ e $14^{\circ}$ do $\S 4^{\circ}$.

$4^{\circ}$. Como, porém, a cidade de Lisboa é muito populosa deverá nomear quatro deputados e a cidade do Porto dois ${ }^{61}$.

\section{\$ 6. \\ Representação pelo comércio e fábricas}

Os negociantes e fabricantes fazem um corpo da Nação de maior contemplação, pelo objeto a que se destinam e interesse que podem fazer à Pátria e, por isso, merecem representação particular, pois não podem ser representados exatamente senão por pessoas da sua classe. Seria árdua coisa a convocação de assembleias primárias em todo o Reino, e como as praças de Lisboa, Porto, Coimbra, Viana, Setúbal, Figueira e Faro são os principais depósitos do negócio

\footnotetext{
${ }^{61}$ Foi riscada a palavra "três".
} 
nacional de maior lote, julgo que será bastante, para fazer uma representação a mais aproximada, o tirar destas os deputados pela forma seguinte:

$\mathbf{1}^{\circ}$. Congregando-se o Senado e negociantes matriculados, ou de nome conhecido na praça, e os fabricantes dela ou do distrito, como no $n .^{\circ} 2$ do $\S 4 .^{\circ}$, se procederá à eleição como no $n .^{\circ} 2^{\circ}$ do $\S 5 .^{\circ}$, com a diferença que cada votante elegerá quinze eleitores e estes procederão à eleição como nos $n .{ }^{\circ} 7^{\circ}, 8^{\circ}, 9^{\circ}$, $10^{\circ}, 11^{\circ}, 12^{\circ}, 13^{\circ}$ e $14^{\circ}$ do $\S 4 .^{\circ}$.

\section{§ 7. \\ Representação do clero secular}

Bastará que o clero secular seja representado por um deputado por cada bispado e, como não seja possivel unir o clero em assembleias primárias por todo o bispado, bastará se façam estas nas capitais dos mesmos bispados, com as mesmas formalidades do $\S 6^{\circ}$, só com a diferença de ser o bispo o presidente e o escrivão da Câmara Eclesiástica quem lavrará os termos competentes.

\section{\& 8..$^{\circ}$ \\ Representação do clero regular}

A representação do clero regular será escusada se os homens fossem capazes daquela perfeição que os faz superiores ao espirito de partido; porém, não sendo possivel esta qualidade nos homens e sendo aliás admitidos pelas nossas instituições politicas tantos cidadãos a esta classe de clero e residindo nele, além disto, tantos motivos de interesse público e particular e até mesmo porque tem sido o asilo de parte da literatura, por isso, julgo que sem injustiça não deverão ser excluidos da representação em Cortes.

1. $^{\circ}$ Poderá fazer-se esta convocando-se, por ordem do prelado maior, as assembleias primárias em cada mosteiro, como no $\S 6 .^{\circ}$, e depois, havendo-se congregado os eleitores na Casa principal da Congregação, perante o prelado maior se fará a eleição dos deputados como nos $n .^{\circ} 7^{\circ}, 8^{\circ}, 9^{\circ}$ e $10^{\circ}$ do $\S 44^{\circ}$.

$\mathbf{2}^{\circ}$. Os prelados maiores das ordens monacais mandarão os nomes dos deputados eleitos pela sua Congregação ao arcebispo de Braga e os das ordens mendicantes ao arcebispo de Évora e cada um destes prelados, juntamente com o deão e cónego magistral do cabido, bem como com o escrivão da Câmara Eclesiástica, procederá a fazer um escrutínio com o nome dos eleitos e aqueles dois primeiros em quem cair a sorte ficarão os deputados representantes pelo clero regular.

$3^{\circ}$. Far-se-á um termo desta eleição em livro que ficará no cartório do escrivão da Câmara e se mandará uma cópia dele, assinado pelos assistentes, aos prelados maiores, dos deputados eleitos para se executar o determinado nos n.os $12^{\circ}, 13^{\circ}$ e $14^{\circ}$ do $\S 4^{\circ}$.

\section{\& 9. \\ Representação pela Universidade}

O corpo da Universidade, por ser o berço das ciências e ser composto de sábios que com suas luzes podem muito ilustrar as Cortes, merece uma representação individual, por faculdade e pelas artes.

1. Convocar-se-á, pois, por ordem do reitor, na Sala da Universidade e na sua presença e do secretário, todo o corpo académico, isto é, lentes e doutores, bem como os mestres do Colégio das Artes, e se procederá na assembleia 
primária como no $\S 6 .^{\circ}$, elegendo-se os eleitores cumulativamente de todo o corpo da Universidade.

$\mathbf{2}^{\circ}$. Os eleitores, porém, nomearão um deputado representante e outro suplementar de cada faculdade e um pelas artes, conformando-se no mais como neste $\S 6 .^{\circ}$ se declara.

\section{$\S 10 .^{\circ}$}

\section{Representação pela Academia Real das Ciências}

A Academia Real das Ciências de Lisboa forma, também, um corpo respeitável e útil à Nação e que pode ser ainda mais útil prestando-se-lhe os meios adequados. Far-se-á a sua representação por dois deputados, cuja eleição se fará na sala das sessões, com assistência do presidente e secretário, por todos os sócios que se acharem em Lisboa, bem como pelos correspondentes, conforme ao $\S 6^{\circ}$, com a advertência que os eleitores poderão escolher qualquer membro da Academia, ainda que não resida em Lisboa.

\section{$\S 11 .^{\circ}$}

Representação pela magistratura

O corpo da magistratura tem todo o direito a representação, não só pela sua qualificação, mas também pelas relações que tem com todas as classes de cidadãos, além do voto decisivo na matéria de legislação. Cada tribunal dará dois deputados e a sua eleição e nomeação se fará como no $\S 11^{\circ}{ }^{\circ}$, sob a presidência dos chefes dos mesmos tribunais.

\section{$\S 12 .^{\circ}$}

\section{Representação pelo corpo militar}

O corpo militar compreende também uma grande massa da Nação e com grandes relações com o politico dela e, por isso, deve ter os seus deputados na forma seguinte: dois pela infantaria, um pela cavalaria, outro pela artilharia e dois pelas milicias.

1. Far-se-á a sua nomeação na presença do comandante de cada corpo, lançando os nomes dos oficiais presentes à urna e tirando-se divididos em três secções, cada uma delas fará eleição dos deputados escolhidos por todo o corpo da sua arma, como nos $n .^{o s} 9^{\circ}$ e $10^{\circ}$ do $\S 44^{\circ}$.

$\mathbf{2}^{\circ}$. Mandar-se-á a cópia do termo de nomeação ao comandante em chefe de todo o exército, o qual, na presença dos seus ajudantes generais e do seu secretário, procederá a fazer escrutinio de todos os nomeados para cada arma e aquele primeiro em quem recair a sorte ficará deputado representante pelo corpo militar, seguindo-se no mais o estabelecido nos $n .^{\circ} 11^{\circ}, 12^{\circ}, 13^{\circ} \mathrm{e}$ $14^{\circ}$ do $\S 4^{\circ}$.

\section{\& 13. ${ }^{\circ}$}

\section{Representação pela Companhia dos Vinhos do Alto Douro}

Ainda que a parte do comércio está já representada, contudo a Companhia dos Vinhos do Alto Douro merece uma particular representação por ser um banco nacional, por ser a sua negociação com uma produção que abrange uma grande parte do Reino e porque as suas correlações se estendem além do mar e com outras Nações.

$\mathbf{1}^{\circ}$. Far-se-á, pois, a nomeação dos deputados chamando à junta todos aqueles que tiverem sido deputados dela e com os deputados atuais se dividirão por 
escrutinio em três secções, cada uma das quais elegerá o seu deputado, como no $\S 10 .^{\circ}$.

\section{Observações gerais}

1. Os deputados devem ser sustentados à custa das corporações a que pertencem, desde a sua saída para as Cortes até à sua volta, com uma contribuição decente e proporcional ao caracter que são requeridos, além de alguma qualificação conforme as circunstâncias particulares da sua pessoa.

$\mathbf{2}^{\circ}$. Entre os deputados em Cortes não haverá diferença ou distinção alguma, sejam eles de que hierarquia forem, e por isso, o seu assento na sala das sessões ou em qualquer parte aonde aparecerem em corpo de representação será sem precedência ou separação, mas dependente da hora e ocasião que se oferecer.

$3^{\circ}$. Haverá uniformidade de vestuário nos deputados, com decência e sem fausto será o traje ordinário casaca, colete, calção ou pantalonas pretas e de lã, de fábrica nacional, podendo o colete ser de seda, mas também nacional, $e$ travão pendente do pescoço com fita de cores da Nação, uma medalha alusiva ao emprego. Nos dias, porém, de grande gala e de cerimónia nas Cortes, quais são, a abertura e o fechamento, quando el-rei vier pessoalmente ou se ponha o selo real a alguma lei ou outras que as Cortes determinem, usarão de toga, como os desembargadores, trazendo, porém, o fato de seda com as cores da Nação e gorra ou chapéu com plumas da mesma cor e a medalha igualmente lançada ao peito, pendente do pescoço. Aqueles deputados que tiverem hábito próprio dele, somente usarão dele, trazendo, porém, a medalha ao peito na forma prescrita. Acabadas as Cortes, não poderão os deputados trazer a medalha lançada do pescoço, mas só presa no lado esquerdo da casaca, enquanto durar o tempo da sua nomeação. Esta medalha pertencerá ao corpo representado e a ele será entregue, pelo deputado, logo que se convoquem as assembleias primárias.

$4^{\circ}$. A duração do emprego de deputado nas Cortes será de três anos, saindo, porém, um terço cada ano; e para dar princípio à renovação se procederá por escrutínio no primeiro ano e depois no segundo, saindo o restante terço no terceiro ano.

\section{Adição ao \$ 4.}

Quando se acha a representação dos proprietários assaz numerosa, pela forma prescrita, se poderá ela diminuir debaixo da mesma maneira representada deste modo:

$\mathbf{1}^{\circ}$. Acabando o termo do $n .^{\circ} 10$ do $\S 4 .^{\circ}$ se passará a cada deputado com o nome de deputado eleito uma cópia dele assinada pelo Senado e, com este documento, comparecerão os deputados de cada concelho que formarem uma comarca civil em dia aprazado na Casa do Senado da cabeça da comarca e ai, em presença do corregedor da comarca, do provedor, do juiz de fora $e$ escrivão da Câmara, depois de se verificarem os documentos das eleições de cada concelho e a identidade dos eleitos se fará termo da reunião em livro determinado para isto assinado por todos os assistentes.

$\mathbf{2}^{\circ}$. Depois, o corregedor declarará aos deputados eleitos que, não podendo todos serem deputados efetivos, neles contudo residia a vontade dos povos de cada concelho, e por isso, que aquele dentre eles que alcançasse maior número de votos ficaria sendo deputado legitimo na classe de representante ou 
suplementar de todos os concelhos que formavam a comarca e que, portanto, se deviam prevenir para votar num daqueles presentes, porque já tinham obtido voto da Nação, com aquela responsabilidade que exigia o bem público e o particular dos concelhos que ia representar e que para mais os ligar ao seu dever lhes deferia o juramento dos Santos Evangelhos.

$3^{\circ}$. Então, entrando a votar separadamente cada um dos deputados perante os três magistrados assistentes, o escrivão da Câmara escreverá numa folha de papel o nome do novo eleito, declarando o concelho a que pertence, e assim irá escrevendo cada nome pela ordem em que forem sendo nomeados extensamente, ainda que nomeados sejam mais do que uma vez, concluidos os votos, assinarão os magistrados e escrivão a sobredita pauta e contandose então os votos, ficará proclamado aquele que tiver maioria de votos e quando entre estes houver empate a sorte decidirá e de tudo se fará no mesmo livro termo, conservando-se no arquivo a pauta de eleição.

$4^{\circ}$. Suceder-se-á, depois, como no n. ${ }^{\circ} 11^{\circ}$ do $\S 4 .^{\circ}$, se passará a carta como no $n{ }^{\circ}$ 12, com a diferença de ser em nome dos magistrados assistentes e de nela também se declarar que, depois da eleição dos deputados de cada concelho, se procedeu a fazer no dia .... do mês .... do ano .... em nossa presença, na Casa da Câmara de .... como capital da comarca, a eleição dos deputados representante e suplementar efetivos, e que por pluralidade de votos e depois por escrutinio, se o houver, saira nomeado para deputado representante proprietário ou para deputado suplementar proprietário de toda a comarca $F . . .$. , morador no lugar .... da freguesia de ..... do concelho ...., e como tal se lhe passava a presente carta credencial, seguindo-se o que fica predito no mesmo $n .^{\circ} 12$ até ao fim.

Penafiel, 23 de outubro de 1820

António de Almeida

Fecha de envio / Submission date: 4/10/2019

Fecha de aceptación / Acceptance date: 7/12/2019 